\title{
Viral and Bacterial Co-Infections in the Lungs: Dangerous Liaisons
}

\author{
Justine Oliva (1) and Olivier Terrier * (1)
}

check for updates

Citation: Oliva, J.; Terrier, O. Viral and Bacterial Co-Infections in the Lungs: Dangerous Liaisons. Viruses 2021, 13, 1725. https://doi.org/ $10.3390 / v 13091725$

Academic Editor: Oliver Schildgen

Received: 20 August 2021

Accepted: 27 August 2021

Published: 30 August 2021

Publisher's Note: MDPI stays neutral with regard to jurisdictional claims in published maps and institutional affiliations.

Copyright: (c) 2021 by the authors. Licensee MDPI, Basel, Switzerland. This article is an open access article distributed under the terms and conditions of the Creative Commons Attribution (CC BY) license (https:// creativecommons.org/licenses/by/ $4.0 /)$.
CIRI, Centre International de Recherche en Infectiologie, (Team VirPath), University Lyon, Inserm, U1111, Université Claude Bernard Lyon 1, CNRS, UMR5308, ENS de Lyon, F-69007 Lyon, France; justine.oliva@univ-lyon1.fr

* Correspondence: olivier.terrier@univ-lyon1.fr

\begin{abstract}
Respiratory tract infections constitute a significant public health problem, with a therapeutic arsenal that remains relatively limited and that is threatened by the emergence of antiviral and/or antibiotic resistance. Viral-bacterial co-infections are very often associated with the severity of these respiratory infections and have been explored mainly in the context of bacterial superinfections following primary influenza infection. This review summarizes our current knowledge of the mechanisms underlying these co-infections between respiratory viruses (influenza viruses, RSV, and SARS-CoV-2) and bacteria, at both the physiological and immunological levels. This review also explores the importance of the microbiome and the pathological context in the evolution of these respiratory tract co-infections and presents the different in vitro and in vivo experimental models available. A better understanding of the complex functional interactions between viruses/bacteria and host cells will allow the development of new, specific, and more effective diagnostic and therapeutic approaches.
\end{abstract}

Keywords: co-infections; superinfections; respiratory infections; respiratory viruses; influenza virus; respiratory syncytial virus; SARS-CoV-2

\section{Respiratory Tract Infections, Their Etiological Agents, and the Weight of Viral-Bacterial Co-Infections}

Respiratory tract infections (RTI) constitute a leading cause of morbidity and mortality worldwide, in children and adults, accounting for approximately 3 to 5 million deaths per year, with a considerable impact on public health and society, and at the economic level [1-3]. RTIs refer to a range of infections confined to the upper respiratory tract (rhinitis, sinusitis, pharyngitis, or tracheitis) and/or lower respiratory tract (mainly bronchitis and pneumonia), implicating microorganisms, including viruses, bacteria, and fungi. The nature of the pathogens involved is very heterogeneous and broad, reflecting many very different infection scenarios. [4]. Co-infections can be defined as concomitant infections, while superinfections are sequential infections by two different pathogens. The most documented scenario in the literature is that of bacterial superinfections following primary viral infection. [5]. The burden of bacterial co-infections and superinfections can be quite different depending on the nature of the primary viral infection.

\subsection{Influenza Viruses}

Post-influenza bacterial pneumonia is known to play a significant role in the morbidity and mortality associated with both seasonal and pandemic influenza virus illness [6]. An important part of pandemic prevention and management is understanding the relationship between influenza infection and secondary bacterial infection [7-10]. Much of our knowledge about the severity of post-influenza bacterial pneumonia comes from retrospective studies in the context of past influenza pandemics. Most deaths in the 1918-1919 influenza pandemic likely resulted directly from secondary pneumonia caused by common 
upper respiratory tract bacteria. Lung tissue samples suggest that most of the estimated 20-60 million deaths were from bacterial superinfections rather than from direct effects of the virus. However, less substantial data from the subsequent influenza pandemics are consistent with these findings [11]. During seasonal epidemics, influenza bacterial co-infection is associated with increases in hospital admission. One in four patients admitted to ICU with severe influenza A infection presented bacterial or viral co-infection [12]. In a national survey in the US during the 2003-2004 influenza season, infectious disease specialists observed a $1.6 \%$ and $2 \%$ rate of bacterial complications in adult and pediatric patients, respectively [13]. Systemic review and meta-analysis revealed that the frequency of bacterial co-infection was highly variable, ranging from $2 \%$ to $65 \%$. In accordance with other studies $[14,15]$, the most prevalent coinfecting bacterial species were Streptococcus pneumoniae and Staphylococcus aureus, which accounted for 35\% (95\% CI, 14-56\%) and 28\% (95\% CI, 16-40\%) of infections, respectively. A wide range of other pathogens, such as Haemophilus pneumoniae or Klebsiella pneumoniae, caused the remaining infections [16]. Teng and collaborators performed a retrospective, observational study during the eight influenza seasons from 2010 to 2018. Of the 209 influenza-associated pneumonia-admitted patients, $41(19.6 \%)$ were identified with community-acquired bacterial co-infections, mainly with $S$. aureus. This phenomenon was frequently observed in influenza-associated pneumonia, but no risk factor has been identified so far. Bacterial co-infection is likely to predict severity and is an independent risk factor for in-hospital mortality. Furthermore, mixed infection with $S$. aureus and influenza has frequently led to a lethal synergism [17].

\subsection{Respiratory Syncytial Virus}

RSV is the most common cause of bronchiolitis in children less than 1-year-old. RSV is also responsible for acute lower respiratory tract infection in the elderly and in immunocompromised adults. The disease is often associated with a simultaneous or secondary bacterial infection. Co-infection with RSV and bacteria is well described, but studies to decipher the underlying molecular mechanisms remain limited (reviewed in [18,19]). Various studies of RSV-infected patients in the hospital revealed an association with a lower respiratory tract bacterial co-infection, ranging from 17.5 to $44 \%$ of patients positive for both RSV and bacterial co-infection. The most common bacteria isolated were S. pneumoniae and H. influenzae [20-22]. However, recent studies suggested a most prevalent association between RSV and S. aureus, especially the methicillin-resistant S. aureus (MRSA) [19]. Bacterial co-infection combined with RSV infection often correlates with more severe disease in susceptible people than simple RSV infection [21,23].

\subsection{SARS-CoV-2}

As of the 9 August 2021, 19 months after its discovery, SARS-CoV-2 has rapidly become a major global pathogen, with the COVID-19 pandemic affecting more than 202 million people and causing more than 4,288,134 deaths worldwide [24]. A large multicenter prospective cohort study recently demonstrated that microbiologically confirmed bacterial infections, mainly secondary, were rare (less than $2.3 \%$ ) in patients admitted to hospital with COVID-19 during the first wave of the pandemic in the UK [25]. This result agrees with several previous observational studies and meta-analyses that have reported a low frequency of bacterial co-infections in people admitted to hospital for COVID-19 [26-29]. Recently, Langford and collaborators performed a meta-analysis with 3338 COVID-19 patients for the evaluation of bacterial co-infection. This phenomenon occurred in $3.5 \%$ of patients $(95 \% \mathrm{CI}$ $0.4-6.7 \%)$, but secondary bacterial infection was also observed in $14.3 \%$ of patients $(95 \% \mathrm{CI}$ 9.6-18.9\%). Generally, the proportion of COVID-19 patients presenting bacterial infection was $6.9 \%$ (95\% CI 4.3-9.5\%). However, bacterial co-infection was more often observed in critically ill patients $(8.1 \%, 95 \%$ CI $2.3-13.8 \%)$. A low frequency of bacterial co-infection was observed in hospitalized patients and may not require anti-bacterial treatment [29]. Similar results were observed in other meta-analysis studies. S. pneumoniae, S. aureus, Pseudomonas aeruginosa, and Escherichia coli were mainly identified, especially in critically ill 
patients. COVID-19 patients with community-acquired co-infections and hospital-acquired superinfections developed the worst outcomes compared to simple-infected patients [30]. Lansbury and collaborators also observed a low frequency of co-infection in COVID-19 patients, with a higher percentage in ICU patients. The most common bacteria detected were Mycoplasma pneumonia, P. aeruginosa, and H. influenzae [28]. Interestingly, a recent study that aimed to determine the incidence of bacterial co-infections in 925 hospitalized COVID-19 patients found that such bacterial co-infections are rare [26]. This finding agrees with earlier retrospective observational studies that reported a low frequency of bacterial co-infection in early COVID-19 hospitalized individuals [27,31]. By contrast, other studies claim that bacterial (and fungal) co-infections exist in severe COVID-19 patients and include Acinetobacter baumannii and K. pneumoniae [32]. Nevertheless, all clinical data show that the bacterial or fungal co-infection rate of SARS-CoV-2-infected patients is lower than in influenza-virus-infected ones. This may be due to an underreporting issue, an extensive use of antibiotics, or the implementation of control measures limiting the spread of several respiratory pathogens. So far, the importance of co-infection in COVID-19 patients and its effects on pathogenesis remains poorly described.

\section{Mechanisms Involved in Co-Infections/Superinfections}

Various mechanisms are involved in respiratory co-infections and superinfections. For a long time, the impact of viral infection on the epithelial barrier was considered the primary cause of bacterial superinfection. Recently, several studies demonstrated that the antiviral immune response also plays a role in mixed infections. Although presented separately in this review (for clarity purposes), physiological and immunological mechanisms are concomitant and closely associated.

\subsection{Physiological Mechanisms \\ 2.1.1. Epithelium Damage}

The epithelium has a crucial role in preventing the invasion of inhaled pathogens and particles. Epithelial cells, assembled in a pseudostratified structure through tight junctions, create an impermeable barrier for pathogens [33]. A sharp decrease of transepithelial resistance and modification of cell morphology were observed in human primary epithelial cells (HAE) cultured at the air-liquid interface after SARS-CoV-2 infection, suggesting a disruption of epithelium integrity [34]. Comparable observations were observed with influenza and RSV using similar in vitro models. A correlation was also noticed in animal models with desquamation, loss of cilia, immune cells infiltration, and necrosis observed after viral infection [35-39]. A dysfunction of tight junctions and cytoskeleton are frequently observed after single viral infection. RSV and influenza viruses can decrease tight junctions by directly or indirectly targeting the proteins involved, such as claudin, occludin, or ZO-1, and induce an F-actin cytoskeleton rearrangement leading to cell morphology modifications [40-42]. In vitro and in vivo co-infection studies demonstrated that the epithelium damage caused by respiratory viruses constitutes one of the causes leading to secondary infection. Primary influenza or RSV infection induce epithelium damage that leads to a higher susceptibility to S. aureus or S. pneumoniae in animal models [43-48]. Viral-induced cell apoptosis can also be responsible for the loss of the epithelium barrier through various mechanisms such as the FasL/TRAIL pathway [49-51]. Although not being specifically studied, some works suggest a correlation between virus-induced apoptosis/necrosis and higher susceptibility to bacterial superinfection, with cell debris improving bacterial adhesion and invasion [52].

\subsubsection{Modification of Airway Function}

Virally induced modifications of airway function are also responsible for respiratory co-infections. The epithelium can thwart infection thanks to mucociliary clearance, which regroups two essential mechanisms: (i) the production of mucus, a multi-component secretion, which entraps the inhaled pathogens [53] and (ii) the presence of motile cilia 
recovering the airway with continuous beating [54]. Epithelial cells are well known to produce mucus after infection to reduce the infection by influenza, RSV, or SARS-CoV-2. However, this leads to airway obstruction, reflecting the diminution of pulmonary capacity observed in patients [53,55]. RSV and influenza viruses are also known to increase mucusassociated protein, such as mucin 5 after infection $[56,57]$. Respiratory viruses mainly target ciliated epithelial cells, inducing cell death and thus, cilia loss. So far, no study has explicitly focused on the molecular mechanisms of mucociliary clearance during co-infection.

\subsubsection{Enhancement of Bacterial Adhesion after Viral Infection}

Primary viral infection can also increase bacterial adherence in the respiratory tract. RSV infection increases the adhesion and the virulence of S. pneumoniae on epithelial cells through direct binding of $\mathrm{G}$ glycoprotein to bacterial components. The $\mathrm{G}$ glycoprotein anchors at the cell membrane after infection and acts as a bacterial receptor [58-60]. A transcriptomic study revealed that RSV increased adherence molecules on RSV-infected cell surfaces, such as CD47, leading to an increased S. pneumoniae adhesion [61]. The influenza virus also enhanced the adhesion of $S$. aureus or S. pneumoniae in various models by increasing fibrinogen, modifications of glycoproteins, and sialic acids on the infected cell membrane $[62,63]$. Platelet-activating factor receptor (PAF-R) has also been described to interact with bacteria, promoting superinfections [64-66]. The influenza glycoproteins hemagglutinin and neuraminidase also promote bacterial adhesion, acting as, or exposing bacterial receptors [67-73]. So far, the effect of SARS-CoV-2 on bacterial adherence during superinfection is poorly described; however, results suggested that another human coronavirus (HCoV-NL63) enhanced S. pneumoniae superinfection in LLC-MK2 and HAE cells but not for other bacteria such as S. aureus, H. influenza, or P. aeruginosa [74].

\subsubsection{Repair Delay after Viral Infection}

Various murine models of superinfection with influenza and S. pneumoniae or S. aureus demonstrated a lethal synergism when the bacteria were inoculated at seven days postinfluenza infection, suggesting that superinfection enhances pathology severity in the later stage of viral infection, during the repair processes. Impairment of repair cell response, especially from macrophages and epithelial cells, was observed, with a decrease in cell regeneration and modification of homeostasis signaling pathway [57,75-77]. RSV can interfere with repair mechanisms by increasing the production of MMPs or growth factors, leading to enhanced fibrosis [78]. Transcriptional profiling of a superinfected mouse model with influenza virus and S. pneumoniae revealed an increase in epithelial cell proliferation and epithelium-repair 48hpi. Moreover, a correlation was observed between gene upregulation and disease severity, suggesting that alteration of the repair mechanism was involved in superinfection [79]. Major and collaborators recently demonstrated that types I and III IFN induced by the influenza virus delayed epithelial cell proliferation during the repair stage. Increased apoptosis through activation of p53 and cell cycle alteration was noticed, leading to cell differentiation and growth inhibition and delayed epithelium repair. Influenza-infected Ifnlr1- / - mice had better survival after superinfection with $S$. pneumoniae, suggesting that IFN- $\lambda$ induced after viral infection delays epithelium repair and contributes to secondary bacterial infection [80].

The physiological mechanisms underlying co-infections are summarized in Figure 1. 


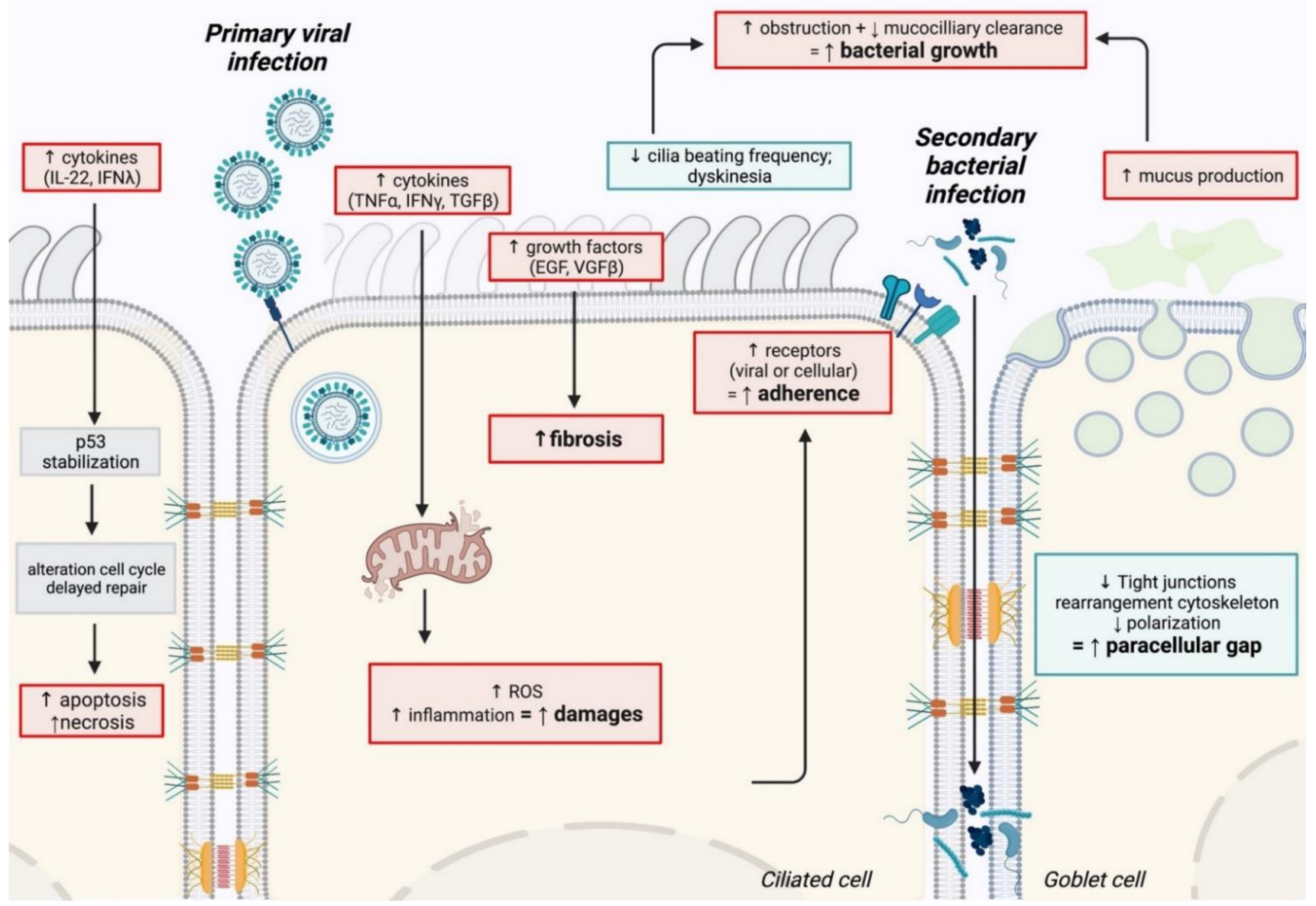

Figure 1. Schematic representation of the physiological mechanisms associated with bacterial superinfections. The impact of the primary viral infection on the integrity and functionality of the epithelium (epithelial damage, repair delay) contributes to creating a favorable environment for the establishment of a secondary bacterial infection. Created with BioRender.com.

\subsection{Immunological Mechanisms}

Recent studies demonstrated that respiratory superinfection is associated with an alteration of the immune response, especially with a lessening of the numbers and functions of innate and adaptive cells [81,82].

\subsubsection{Innate immunity}

The first line of defense is innate immune cells such as airway macrophages (AM), monocytes, neutrophils, natural killer (NK) cells, dendritic cells (DC), and epithelial cells [83-86], sense respiratory pathogens by different pattern recognition receptors (PRRs), such as the Toll-like receptors (TLRs) (TLR3 and TLR7/8 and, to a lesser extent, TLR4, TLR2, and TLR9), retinoic acid-inducible gene I (RIG-I), and NOD-like receptors (NLRs), especially inflammasome NLRP3 [87-93]. Their engagement induces the activation of transcription factors (IRF3, IRF7, and NF- $\mathrm{BB}$ ), eliciting the production of pro-inflammatory effectors such as type I and III interferons (IFN), pro-inflammatory cytokines (IL-1 $\beta$, IL6, IL-18, and TNF $\alpha$ ) and chemokines (IP-10, RANTES, CCL2, MIP-1, and IL-8) [94-100]. Primary viral infection by influenza led to a downregulation of various TLRs, such as TLR2, TLR4, and TLR5, inducing an irresponsiveness to secondary bacterial infection and thus a decreased bacterial clearance [101]. PRRs, such as TLR9, TLR3, or RIG-I, also had a detrimental role in mixed influenza or RSV/bacterial infection [102,103]. Little is known about the effect of co-infection on inflammasome, but primary viral infection seemed to influence its activation and the production of IL-1 $\beta$, crucial for bacterial clearance [104]. 
Superinfection after viral infection impairs the recruitment and/or the functions of innate immune cells. Influenza virus infection in mice led to a depletion of $90 \%$ of alveolar macrophages, and the remaining $10 \%$ presented a necrotic profile associated with increased susceptibility to $S$. pneumoniae $[105,106]$. Other studies suggested dysfunctional macrophages rather than impaired recruitment led to bacterial superinfection, with a dampened activation mediated with STAT2-dependent pathway, or decreased phagocytosis and apoptosis caused by the downregulation of the scavenger receptor MARCO [107,108]. Various studies demonstrated the impairment of ROS production after RSV or influenza infection, promoting secondary bacterial infection [109-111]. Contrary to alveolar macrophages, neutrophilia are observed after RSV and influenza infection. Surprisingly, neutrophil depletion was not associated with susceptibility to secondary infection, suggesting impaired function was responsible for bacterial clearance decrease [112-114]. Primary viral infection dampened neutrophil killing processes, such as ROS production and phagocytosis, leading to decreased bacterial clearance $[86,111,115]$. Despite an increased formation of neutrophil extracellular traps (NETs) after RSV and influenza infection, their dysregulated functions led to an inability to control secondary bacterial infection by S. pneumoniae [116,117].

Other innate cells are modulated during co-infections. Inflammatory monocytes promote epithelium injury through an influenza-induced TRAIL-dependent mechanism, promoting secondary infection [118]. Influenza-induced NK cell impairment leads to uncontrolled proliferation of S. aureus [119]. Moreover, activation of dendritic cells (DCs) is usually inhibited after influenza and RSV infection. Although the role of DCs in coinfections is still unknown, an alteration of their functions might decrease $\mathrm{T}$ cells response and increased susceptibility to co-infection [120-122]. Little is known about the effect of SARS-CoV-2 during co-infections or its role on innate immune cells. Various clinical and in vivo studies described an alteration of innate immune cells, characterized by an increased/decreased number of immature phenotypes that could lead to superinfection $[123,124]$.

Innate immune cells are also significant producers of cytokines and chemokines, with a crucial role in controlling and resolving infection. Influenza infection was shown to dampen the production of pro-inflammatory IL- $1 \beta$, IL- 6 , and TNF- $\alpha$, leading to a decreased bacterial clearance [119]. The importance of balance between IL-13 and IFN- $\gamma$ was brought to light during dual infection-decreased IL-13 and its IFN- $\gamma$-inhibitory property increased bacterial susceptibility [125]. A crucial role of IL-10, an anti-inflammatory cytokine secreted in the later stage of influenza or RSV infection, was also observed in superinfections. A regulation of neutrophil and macrophage activity was also observed during superinfection, suggesting that IL-10 inhibited innate immune response against a second pathogen $[115,126,127]$. Analysis of transcriptomic signatures revealed an increase of IP-10 (CXCL-10) during co-infection with RSV or influenza and bacteria, promoting the recruitment of immune cells and contributing to lung pathology [128,129]. Type I interferons (IFN- $\alpha / \beta$ ) have a crucial role in early antiviral immunity through the induction of hundreds of interferon-stimulated genes (ISGs). Still, distinct effects were also observed on the outcome of bacterial infection [130]. Various studies using transgenic mouse models demonstrated the detrimental role of type I IFN in subsequent bacterial infection following virus infection, with an inhibition of neutrophil recruitment and function and type 17 immune response [131-135]. Shepardson and collaborators noticed a distinct role of type I IFNS, with IFN- $\beta$ reducing MRSA susceptibility in the pre-clinical stage of influenza infection and IFN- $\alpha$ promoting the susceptibility in the clinical stage [136]. Co-infection with influenza virus and S. pneumoniae increased the expression of many miRNAs, such as miRNA-200a-3p, leading to an inhibition of the JAK-STAT inhibitor SOCS6, and this might increase the production of type I-IFNs exacerbating their detrimental effect [129]. Recent studies demonstrated that type III interferons are crucial in promoting superinfections, with similar mechanisms to type I IFN $[137,138]$. 


\subsubsection{Adaptive Immunity}

Adaptive response, including T CD8+ and T CD4+ cell and antibody responses, is essential to resolving the respiratory infection. Numerous studies in mouse models with influenza virus and S. aureus demonstrated the importance of type 17 response, especially the production of IL-17 and IL-22, for efficient bacterial clearance. A recent study demonstrated that IL-22BP- / - mice are protected during influenza and bacterial super-infection, suggesting that IL-22-binding protein has a pro-inflammatory role and impairs epithelial barrier function likely through interaction with IL-22 [139]. Mixed infections decreased cytokine production by Th17 and $\gamma \delta \mathrm{T}$ cells, and thus impaired bacterial clearance. Type I IFNs impaired the activation of Th17 through a decreased IL-23 and IL- $1 \beta$ production by dendritic cells. STAT1 also had a role in dampening type 17 response, as STAT1- / mice better controlled secondary bacterial infection than WT mice. Finally, IL-27, known to interfere with type 17 response, was enhanced in mixed infection [132,140,141]. A detrimental role of Th1 cells was observed in CD4-depleted CD8 $\alpha-/-$ mice, with an improved bacterial clearance related to decreasing production of IFN- $\gamma$ [108]. Although no study has demonstrated their role so far, regulatory T cells (Tregs) might be responsible for IL-10 production in the later stage of infection, thus increasing susceptibility to bacterial infection. Tregs could inhibit T CD8+ and T CD4+ cell functions and/or recruitment $[126,142]$. Blevins and collaborators noticed a depletion of T CD8+ cells and a decrease of IFN- $\gamma$ and TNF- $\alpha$ by remaining T CD8+ cells, which may lead to secondary infection. T CD8+ cells also have a detrimental role on other cells, as IFN- $\gamma$ producing T CD8+ cells inhibited the anti-bacterial function of macrophages in the recovery stage [108]. So far, the role of humoral response in co-infection is still poorly understood, and divergent results have been observed. Wu and collaborators noticed a dampened T CD4+ cells, associated with a decreased B-cell- and antibody response, whereas Wolf and collaborators observed an increase in antibody response [143,144]. Recently, the role of innate-like unconventional cells such as $\gamma \delta \mathrm{T}$ cells, mucosal-associated invariant T (MAIT) cells, or invariant natural killer $\mathrm{T}$ (iNKT) cells, situated at the interface of innate and adaptive immunity, was described during co-infection. Post-influenza infection by S. pneumoniae induced a decrease of IFN$\gamma$-producing iNKT as well as IL-17-producing $\gamma \delta$ T cells, through a type I IFN-dependent manner, increasing the susceptibility to secondary bacterial infection $[133,145,146]$.

\subsubsection{Other Mechanisms}

The dysregulation of immune response and the alteration of airway epithelium aside, other mechanisms are also involved in respiratory co-infections. For example, McCauley and collaborators demonstrated that the accessory influenza protein PB1-F2, especially the C-terminal domain of the protein, increased the inflammation and the frequency/severity of superinfections. Another study also demonstrated that PB1-F2 contributed to inflammation through a mitochondria-mediated cell death but was restricted to the lab strain PR8 [147-149].

The overall immunological mechanisms underlying co-infections are summarized in Figure 2. 


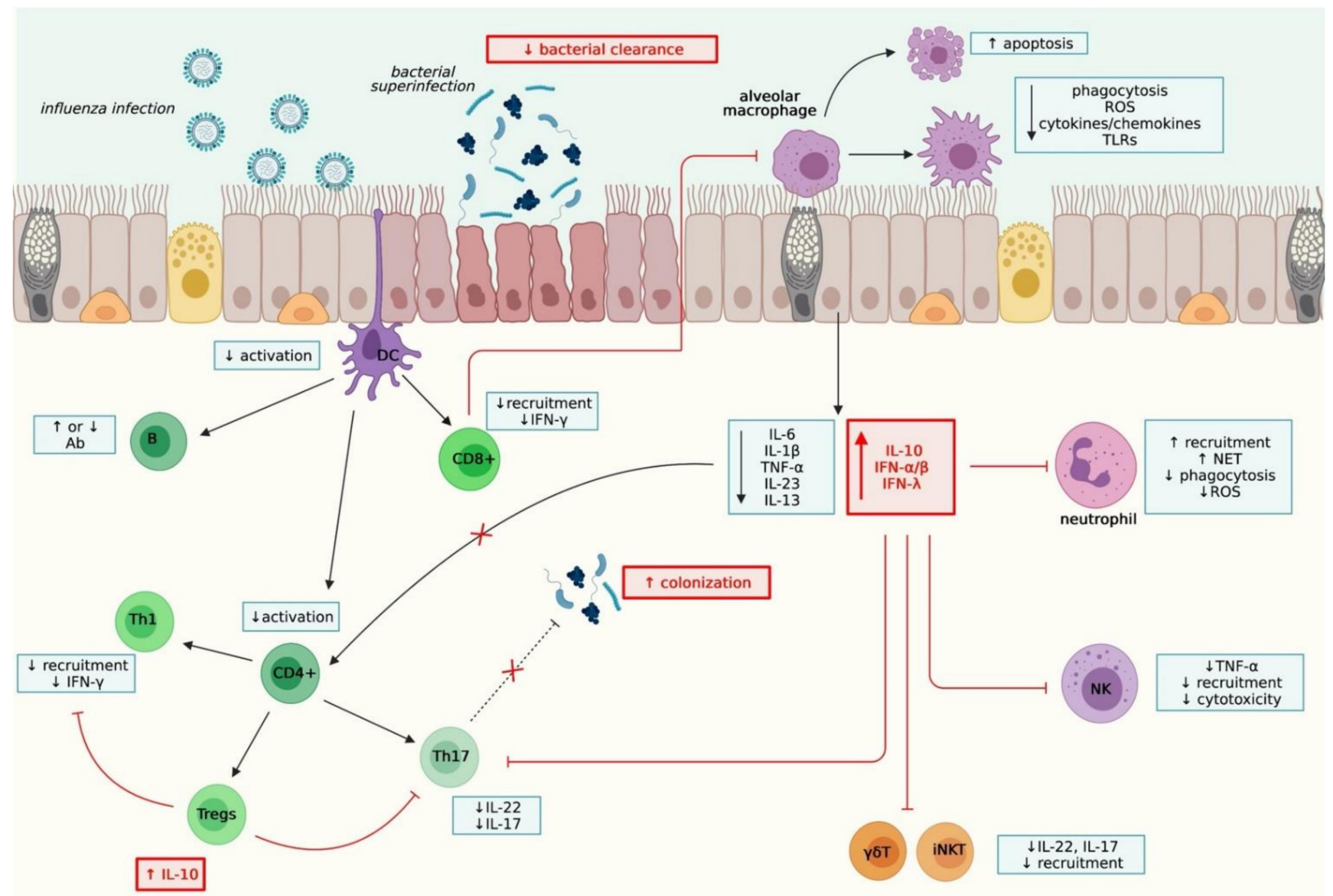

Figure 2. Schematic representation of the immunological mechanisms underlying virus-bacteria co-infections. These mechanisms involve different cell types, in closely related innate and adaptive immune responses. The regulation of the magnitude and timing of these responses plays an essential role in the balance between colonization and bacterial clearance. Created with Biorender.com.

\section{Viral and Bacterial Co-Infections in the Context of Chronic Respiratory Diseases}

There is now a broad consensus that airway infections constitute a significant risk for patients with chronic respiratory diseases, such as asthma, chronic obstructive pulmonary disease (COPD), or cystic fibrosis (CF) [150,151]. Nevertheless, the underlying mechanisms involving co-infections between bacteria and viruses are still relatively poorly characterized.

In $\mathrm{CF}$, an autosomal recessive disease affecting nearly 70,000 people worldwide, respiratory infections play an essential role in the development and progression of lung disease, $P$. aeruginosa and S. aureus being the predominant primary causative agents [152-154]. However, the underlying mechanisms that explain the severity of infections in CF patients are still not well understood. A large majority of $\mathrm{CF}$ patients die due to respiratory failure caused by chronic bacterial infection and concomitant airway inflammation [150]. Several factors are well known to favor bacterial bronchial colonization, such as mucus hyperviscosity, increased bacterial adhesion via the overproduction of ganglioside-type cell receptors, and a decrease in immune defenses. In this context, early infection of the airways with bacteria such as S. aureus or S. pneumoniae, followed by later chronic infection with P. aeruginosa, is a major clinical problem for patients, as these infections are very quickly accompanied by severe deterioration in lung function [150]. Several studies suggest that viral respiratory infections significantly alter the lung environment, creating conditions favorable for bacterial colonization and subsequent patient disease exacerbation [155]. For example, RSV infection has been shown to increase the binding of P. aeruginosa to primary lung epithelial cells in vitro, including through the promotion of biofilm formation [156]. The 
impaired immune response following viral infections, also observed in other types of chronic respiratory diseases (e.g., asthma and COPD), may also facilitate secondary bacterial colonization contributing to disease severity [155]. Surprisingly, the scenario of chronic primary bacterial colonization, which emphasizes the impact of secondary viral infection, a case frequently encountered in $\mathrm{CF}$, remains relatively unexplored in the literature. The associated molecular mechanisms at the level of cellular signaling pathways are not yet fully elucidated. A comprehensive review of virus/bacteria co-infections in the context of CF has recently been published by Kiedrowski and Bomberger [157].

Both viral and bacterial infections are also associated with exacerbations of chronic obstructive pulmonary disease (COPD) [158]. A wide variety of respiratory viruses have been implicated as playing a role in bacterial exacerbations of COPD due to the H. influenzae, M. catarrhalis, S. aureus, P. aeruginosa, and Enterobacter spp. In line with these observations, a recent study found that 15 days after experimental rhinovirus infection of subjects with COPD, there was a sixfold increase of the $16 \mathrm{~S}$ copy number detected in sputum compared to baseline values obtained from sputum collected before RV inoculation [159]. The succession of viral and/or bacterial infections during childhood, and their long-term consequences on the immune response, could constitute a favorable ground for the development of asthma. The involvement of bacteria such as S. pneumoniae or H. influenzae and recurrent viral infections by RSV have been described and considered critical factors $[160,161]$. Nevertheless, there is currently little information on a specific contribution to viral/bacterial co-infections.

\section{What about the Microbiome?}

For a long time, the respiratory tract was considered a sterile environment, and the presence of bacteria was associated with acute or chronic infection. The discovery of a respiratory microbiome started with the Human Microbiome Project in 2008, thanks to the development of high-throughput sequencing using the $16 \mathrm{~S}$ rRNA gene [162]. Since then, various studies have demonstrated the presence of microbiome in the upper respiratory tract (URT) and lower respiratory tract (LRT) and its importance for lung homeostasis [163]. Since the last decade, numerous studies were performed to understand the influence of viral infection on the microbiome. Various NGS studies demonstrated that RSV and influenza virus altered the respiratory microbiome through direct or indirect processes, inducing a dysbiosis [164-167]. Metagenomic studies performed on infected human samples by respiratory virus demonstrated a shift from Bacteroidetes to Proteobacteria, including numerous Gram-negative pathogenic bacteria [167,168].

So far, bacterial colonization of the URT is considered as the first stage of bacterial invasion in the lungs after primary viral infection. It has been demonstrated that influenza virus and RSV enhance bacterial adherence and colonization, leading to secondary infection and pneumonia $[58,70]$. Besides, influenza virus also promoted S. pneumoniae transmission in mice [169]. Moreover, influenza-virus-induced signals, such as the release of ATP, lead to increased dispersed bacteria from biofilm, associated with a pathogenic phenotype [170,171]. Using RNA-seq, Pettigrew and collaborators characterized the effect of influenza virus on S. pneumoniae. An enhanced expression of several genes involved in bacterial metabolism and motility was observed in dispersed bacteria, suggesting that influenza virus could directly or indirectly influence commensal S. pneumoniae phenotype [172]. Another possibility could be that by altering the microbiome, a viral infection might decrease bacteria species that usually keep at bay pathogenic bacteria and thus, protect the host. Discrepancies exist about the respiratory microbiome and the disease severity. Some studies demonstrated an association between increased diversity and influenza or RSV infection severity, while others showed the contrary. Besides, divergent results were observed about the association of dysregulation of microbiome species and viruses. For example, some studies revealed a positive association between RSV and $H$. influenzae or the influenza virus and S. aureus, while others failed to observe this effect [166]. 
Viral infections might also induce a different host state that promotes microbiome alteration and secondary bacterial infection. During viral infection, the increase of inflammation through the production of cytokines could create a suitable environment for proliferation of some commensal bacteria, such as S. pneumoniae or S. aureus. Type III IFN induced after influenza infection was associated with a restructuring and expansion of the nasal microbiome, as observed for Klebsiella. Moreover, an increase of secondary infection by S. aureus was also observed after viral infection, suggesting an interplay between microbiome and pathogens during co-infections $[137,138]$. Until then, studies of co-infections were mainly based on the interaction between two pathogens without considering the lung microbiota. However, it is crucial to consider the respiratory microbiome as it could influence the mechanism leading to co-infections and could be a therapeutic target. Recently, Kanmani and collaborators observed the interplay between co-infection and the microbiome. Using a commensal nasal bacterium (C. pseudodophteriticum) as a probiotic in the infant mouse model, they observed an improved antiviral immune response against RSV and a subsequent infection by S. pneumoniae [173]. Other studies demonstrated bacteria interspecies competition, which could alter co-infection between virus and bacteria [166].

\section{What Are the Best Models for Studying Co-Infections?}

Many different models have been used to study co-infections (Table 1); each model has advantages and disadvantages, depending on the nature of the pathogens studied and the experimental objectives. It is therefore difficult to say which model is the best, as they are all very complementary.

Table 1. Overview of the available experimental models for the study of viral/bacterial co-infections, with their respective advantages and drawbacks.

\begin{tabular}{|c|c|c|c|c|}
\hline \multicolumn{2}{|c|}{ Experimental Models } & Advantages & Drawbacks & References \\
\hline \multirow{2}{*}{ In vitro } & $\begin{array}{c}\text { Cell monolayers } \\
\text { (Cell lines/primary cells) }\end{array}$ & $\begin{array}{c}\text { Easy handling/practical } \\
\text { Low cost }\end{array}$ & $\begin{array}{l}\text { Limited biological } \\
\text { relevance }\end{array}$ & {$[128,174,175]$} \\
\hline & Reconstituted HAE & Physiological relevance & High cost & [129] \\
\hline \multirow{4}{*}{ In vivo } & Mouse & $\begin{array}{c}\text { Low cost } \\
\text { Availability } \\
\text { Transgenic/Humanized/KO } \\
\text { models }\end{array}$ & $\begin{array}{l}\text { Limited biological } \\
\text { relevance }\end{array}$ & {$[45,46,59,113,176-180]$} \\
\hline & NHP & \multirow{3}{*}{ Physiological relevance } & \multirow{3}{*}{$\begin{array}{c}\text { High cost } \\
\text { Ethical concern } \\
\text { High complexity } \\
\text { Availability of reagents }\end{array}$} & {$[43,44,181,182]$} \\
\hline & Ferret & & & [183] \\
\hline & Human challenge & & & [184] \\
\hline
\end{tabular}

\subsection{In Vitro Models}

Compared to the large number of clinical studies or in vivo experiments, there are relatively few experimental models of in vitro co-infections/superinfections described in the literature. Several in vitro superinfection models using monolayer cell lines or primary cells derived from epithelia or macrophages have been proposed-influenza/S. aureus in A549 cells [174,175], or RSV / S. pneumoniae in primary macrophages [128] provide important information on the host response and mutual virus/bacteria interactions. Although essential, these models present some limitations. Beyond the biological relevance, which may be questionable for some cell lines, the mode of infection/superinfection of bacteria in the cell supernatant (planktonic bacteria) may not always represent what happens in patients. To study co-infections/superinfections in a much more physiological context, several teams are now working with reconstituted human epithelial models, consisting of primary differentiated respiratory cells grown at the air-liquid interface [129]. These experimental models allow a much more integrated approach, as it is possible to simultaneously study the impact of co-infections/superinfections on the physiology of the epithelium 
(monitoring of trans-epithelial resistance), but also on the immune response (measurement of cytokines/chemokines at the apical/basal level) or, more broadly, on the global response of the host (transcriptome/proteome, etc.). Other, more complex models, such as lungon-chip or lung-organoids (reviewed in [185]), are also promising models for studying co-infections. These models are still quite costly and require significant expertise, limiting their use on a large scale.

\subsection{In Vivo Models}

Laboratory animal models have a crucial role in pre-clinical studies for vaccines or therapeutics approaches, especially for assessing efficacy and safety, but also essential to studying pathogenesis and transmission of pathogens. A good model needs to simulate, pathogen replication, host response, and clinical signs as closely as possible to what would happen in humans. However, there are various points to keep in mind in the choice of the model, such as study goals, availability of reagents, and animal background [186].

\subsubsection{Mouse Model}

The mouse model is widely used to model infectious diseases. Its main advantage is practicality with low cost, size, husbandry requirements, the availability of reagents, and the possibility of using transgenic, humanized, or knock-out mice to study different host responses. However, this model also presents disadvantages such as semi-permissive replication or the need for strain adaptation to induce viral replication and disease in the lungs, or the absence of viral receptors, as well as different signs of disease compared to human disease and the influence of genetic background [187-190]. Different superinfection models were developed, especially with influenza virus and secondary infection with S. pneumoniae or S. aureus. Mice primarily infected with influenza and subsequently with S. pneumoniae or S. aureus mimicked very well what is observed in children with a mixed respiratory infection. Synergism was observed between both pathogens, with an increase in morbidity and mortality associated with higher bacterial load in the lungs and increased lung injury. On the contrary, simultaneous infection presented an additive effect, suggesting that interval for sequential infection is decisive. Finally, primary bacterial infection prevented secondary infection by influenza, suggesting the importance of the order of the pathogens, with the underlying mechanisms explaining these differences remaining to be better characterized. Mouse models were also developed to study co-infection between RSV and S. pneumoniae or S. aureus. Similarly, influenza mixed infection resulted in higher susceptibility to secondary infection in mice. However, simultaneous infection of RSV and S. pneumoniae or S. aureus in mice resulted in higher bacterial load than sequentially infected mice, suggesting different outcomes depending on the pathogens $[46,59,113,176,177]$. Altogether, these studies demonstrated that the mouse model is an attractive model to study mixed infections. So far, all the data available about the effect of dual infection on the host immune response were obtained using the mouse model, thanks to transgenic and knock-out mice $[45,64,72,178-180]$.

\subsubsection{Non-Human Primate Model}

Due to physiology and genetic similarities, non-human primates (NHP) are the closest model to study human respiratory viruses. They present similar morphology and reproduce the features of human pneumonia. However, high cost, practical aspects, and ethical considerations lead NHP to be less accessible. Different NHP species models have been developed for RSV, influenza, and SARS-CoV-2, and simple bacterial infection with different results depending on the species [188-192]. The first study of dual respiratory infection in NHP was performed in squirrel monkeys infected with influenza virus following by S. pneumoniae four days later. Primary viral infection potentiated secondary bacterial infection, leading to severe pneumonia and high bacterial load in the lungs compared to single-infected animals [44]. More recent studies demonstrated similar results in infection various influenza strains, such as H3N2, H1N1, and H7N7 associated with S. aureus. Mixed 
infection increased morbidity and mortality compared to single infection, and results in NHP were more consistent with dual infection observed in healthy humans $[43,181]$. Vaccination against H7N7 prevented disease by decreasing morbidity associated with reduced viral replication and, to a lesser extent, bacterial load, suggesting a role of vaccine to minimize co-infections [182]. So far, no model exists for mixed infection involving RSV or SARS-CoV-2 with bacteria.

\subsubsection{Ferret Model}

Ferrets are a valuable model for studying human respiratory viruses, as similar pathology has been observed in different infection models. For influenza viruses, the main advantage is that adaptation is not required to induce disease in the animals. However, a major drawback of this model is the limited availability of reagents and immunological tools to study the response to infection. Recently, this model was also used to study human RSV, but only mild clinical signs were recorded. Finally, experimental infection by SARS-CoV-2 demonstrated that ferrets might not be the most relevant with a predominant upper-respiratory tract infection $[190,193]$. Ferrets have been used to study bacterialrelated pneumonia, such as S. pneumoniae or S. aureus, as well as P. aeruginosa in the case of cystic fibrosis [194-196]. Enhanced bacterial adherence was observed in the nasal mucosa of influenza-infected ferrets, suggesting a synergism between those two pathogens in this model [183]. As observed in humans, more severe illness was observed in mixed infection compared to the simple one, with a higher bacterial load in the upper respiratory tract. Similarly, in human disease, mild to severe histopathology lesions were observed. Depending on influenza viral strain or subtype, the outcome of secondary infection was different, as H3N2 induced more severe sinusitis compared to influenza B virus (IBV), for example, thus supporting epidemiological data [194]. Moreover, the pneumonia severity of dual infection was also dependent on S. pneumoniae strains [197].

\subsubsection{Other Models of Interest}

Other models have also been used the study the importance of co-infections in respiratory disease. Nguyen and collaborators developed a co-infection model in cotton rats to understand the interaction between RSV and S. pneumoniae. Primary bacterial colonization followed by RSV infection led to an increased viral replication in the respiratory tract, but with dependence on S. pneumoniae strains [198]. Higher bacterial load and lung injury were also observed in cotton rats infected with influenza and S. aureus; however, no clinical signs were observed in single or co-infected animals [199]. Other studies used the chinchilla model to study otitis media in mixed infections involving RSV or influenza viruses. Primary viral infection enhanced the severity of the disease by promoting bacterial replication [200,201]. Human challenges have been performed since the 1930s, mainly to characterize influenza infection, but they became rare and challenging to set up in the 1990s due to more strict regulations [184]. Recently, Jochems and collaborated used a human model challenge to assess host change in mixed influenza virus and S. pneumoniae infection in the nasal tract. Fifty-three volunteers were infected with a live-attenuated influenza virus (LAIV) and three days later with S. pneumoniae. Viral infection increased bacterial acquisition and carriage compared to simple infection. Moreover, higher production of cytokines such as IP-10, IL-15, IL-10, or IFN- $\gamma$ was associated with mixed infection. Analysis of host gene signatures revealed an alteration of innate immune genes such as PRRs, type I and II IFN, or interleukins, underlining that LAIV improved secondary bacterial infection by altering the host response. Surprisingly, contrary to the mouse model, type 17 response was not involved in higher susceptibility to mixed infection, demonstrating that animal models might not reflect human disease [202].

\section{Concluding Remarks}

Respiratory tract co-infections are a model of complex functional interactions between viruses/bacteria and host cells. The nature of the different pathogens involved, the mi- 
crobiological and cellular contexts, the sequence and timing of infections are essential parameters that determine the underlying physiological and immunological mechanisms of disease severity. Given this complexity, at the fundamental level, to deepen our understanding of the role of co-infections in the aggravation of respiratory pathology, it will be necessary to combine different techniques in an integrated approach, trying to work on the most relevant experimental models in terms of physiology. Some specific areas of research probably deserve particular attention. Future work is needed to better understand, for example, the key role played by the sequence and timing of infections, or the detrimental role of the innate immune response often observed in bacterial superinfections. In addition to deciphering the mechanisms underlying the severity, the study of co-infections of the respiratory tract is also likely to provide new diagnostic and therapeutic solutions. The identification of biomarkers of severity, for example, could allow more rapid and effective management of patients. At the same time, host-targeted therapeutic approaches could qualify for more appropriate treatment of co-infections, less likely to be subject to the emergence of antiviral and/or antibiotic resistance. Respiratory co-infections remain an unexplored territory, and their study will undoubtedly bring us many surprises and hopefully new tools to fight them.

Author Contributions: Conceptualization, J.O. and O.T.; writing-original draft preparation, J.O. and O.T.; writing-review and editing, J.O. and O.T.; visualization, J.O. and O.T.; project administration, J.O. and O.T.; funding acquisition, O.T. All authors have read and agreed to the published version of the manuscript.

Funding: This work was supported by grants from Agence National de la Recherche (ANR JCJC Ho-TARI) and Fondation Air Liquide (COEPIMUS project).

Acknowledgments: The authors would like to thank all members of VirPath Team (Centre International de Recherche en Infectiologie) for their help and continuous support.

Conflicts of Interest: The authors declare no conflict of interest.

\section{References}

1. WHO. Acute Respiratory Infections. Available online: http://apps.who.int/vaccine_research/diseases/ari/en/index.html (accessed on 3 June 2016).

2. Schluger, N.W.; Koppaka, R. Lung Disease in a Global Context. A Call for Public Health Action. Ann. Am. Thorac. Soc. 2014, 11, 407-416. [CrossRef] [PubMed]

3. Roth, G.A.; Abate, D.; Abate, K.H.; Abay, S.M.; Abbafati, C.; Abbasi, N.; Abbastabar, H.; Abd-Allah, F.; Abdela, J.; Abdelalim, A.; et al. Global, regional, and national age-sex-specific mortality for 282 causes of death in 195 countries and territories, 1980-2017: A systematic analysis for the Global Burden of Disease Study 2017. Lancet 2018, 392, 1736-1788. [CrossRef]

4. Mandell, L.A. Etiologies of Acute Respiratory Tract Infections. Clin. Infect. Dis. 2005, 41, 503-506. [CrossRef] [PubMed]

5. Bello, S.; Mincholé, E.; Fandos, S.; Lasierra, A.B.; Ruiz, M.A.; Simon, A.L.; Panadero, C.; Lapresta, C.; Menendez, R.; Torres, A. Inflammatory response in mixed viral-bacterial community-acquired pneumonia. BMC Pulm. Med. 2014, 14, 123. [CrossRef]

6. Metersky, M.L.; Masterton, R.G.; Lode, H.; File, T.M.; Babinchak, T. Epidemiology, microbiology, and treatment considerations for bacterial pneumonia complicating influenza. Int. J. Infect. Dis. 2012, 16, e321. [CrossRef] [PubMed]

7. Rice, T.W.; Rubinson, L.; Uyeki, T.M.; Vaughn, F.L.; John, B.B.; Miller, R.R.; Higgs, E.; Randolph, A.; Smoot, B.E.; Thompson, B.T. Critical illness from 2009 pandemic influenza A virus and bacterial coinfection in the United States. Crit. Care Med. 2012, 40, 1487-1498. [CrossRef]

8. Randolph, A.G.; Vaughn, F.; Sullivan, R.; Rubinson, L.; Thompson, B.T.; Yoon, G.; Smoot, E.; Rice, T.; Loftis, L.L.; Helfaer, M.; et al. Critically Ill Children During the 2009-2010 Influenza Pandemic in the United States. Pediatrics 2011, 128, e1450-e1458. [CrossRef] [PubMed]

9. Palacios, G.; Hornig, M.; Cisterna, D.; Savji, N.; Bussetti, A.V.; Kapoor, V.; Hui, J.; Tokarz, R.; Briese, T.; Baumeister, E.; et al. Streptococcus pneumoniae Coinfection Is Correlated with the Severity of H1N1 Pandemic Influenza. PLoS ONE 2009, 4, e8540. [CrossRef] [PubMed]

10. Nguyen, A.; Noymer, A. Influenza Mortality in the United States, 2009 Pandemic: Burden, Timing and Age Distribution. PLoS ONE 2013, 8, e64198. [CrossRef] [PubMed]

11. Morens, D.M.; Taubenberger, J.K.; Fauci, A.S. Predominant Role of Bacterial Pneumonia as a Cause of Death in Pandemic Influenza: Implications for Pandemic Influenza Preparedness. J. Infect. Dis. 2008, 198, 962-970. [CrossRef]

12. Blyth, C.C.; Webb, S.A.R.; Kok, J.; Dwyer, D.E.; van Hal, S.; Foo, H.; Ginn, A.N.; Kesson, A.M.; Seppelt, I.; Iredell, J.R.; et al. The impact of bacterial and viral co-infection in severe influenza. Influ. Other Respir. Viruses 2013, 7, 168-176. [CrossRef] 
13. Podewils, L.J.; Liedtke, L.A.; McDonald, L.C.; Hageman, J.C.; Strausbaugh, L.J.; Fischer, T.K.; Jernigan, D.B.; Uyeki, T.M.; Kuehnert, M.J.; Network, T.I.D.S.O.A.E.I. A National Survey of Severe Influenza-Associated Complications among Children and Adults, 2003-2004. Clin. Infect. Dis. 2005, 40, 1693-1696. [CrossRef]

14. Wong, K.K.; Jain, S.; Blanton, L.; Dhara, R.; Brammer, L.; Fry, A.M.; Finelli, L. Influenza-Associated Pediatric Deaths in the United States, 2004-2012. Pediatrics 2013, 132, 796-804. [CrossRef]

15. Finelli, L.; Fiore, A.; Dhara, R.; Brammer, L.; Shay, D.; Kamimoto, L.; Fry, A.; Hageman, J.; Gorwitz, R.; Bresee, J.; et al. InfluenzaAssociated Pediatric Mortality in the United States: Increase of Staphylococcus aureus Coinfection. Pediatrics 2008, 122, 805-811. [CrossRef]

16. Klein, E.Y.; Monteforte, B.; Gupta, A.; Jiang, W.; May, L.; Hsieh, Y.; Dugas, A. The frequency of influenza and bacterial coinfection: A systematic review and meta-analysis. Influ. Other Respir. Viruses 2016, 10, 394-403. [CrossRef]

17. Teng, F.; Liu, X.; Guo, S.-B.; Li, Z.; Ji, W.-Q.; Zhang, F.; Zhu, X.-M. Community-acquired bacterial co-infection predicts severity and mortality in influenza-associated pneumonia admitted patients. J. Infect. Chemother. 2019, 25, 129-136. [CrossRef] [PubMed]

18. Griffiths, C.; Drews, S.J.; Marchant, D.J. Respiratory Syncytial Virus: Infection, Detection, and New Options for Prevention and Treatment. Clin. Microbiol. Rev. 2017, 30, 277-319. [CrossRef]

19. Pacheco, G.; Gálvez, N.; Soto, J.; Andrade, C.; Kalergis, A. Bacterial and Viral Coinfections with the Human Respiratory Syncytial Virus. Microorganisms 2021, 9, 1293. [CrossRef] [PubMed]

20. Jiang, W.; Wang, T.; Li, L.; Ji, W.; Wang, Y.; Yan, Y. Impact of bacteria in nasal aspirates on disease severity of bronchiolitis. Infect. Dis. 2016, 48, 82-86. [CrossRef] [PubMed]

21. Korppi, M.; Leinonen, M.; Koskela, M.; Mäkelä, P.H.; Launiala, K. Bacterial coinfection in children hospitalized with respiratory syncytial virus infections. Pediatr. Infect. Dis. J. 1989, 8, 687-692. [CrossRef] [PubMed]

22. Randolph, A.; Reder, L.; Englund, J.A. Risk of Bacterial Infection in Previously Healthy Respiratory Syncytial Virus-Infected Young Children Admitted to the Intensive Care Unit. Pediatr. Infect. Dis. J. 2004, 23, 990-994. [CrossRef] [PubMed]

23. Lee, N.; Lui, C.Y.G.; Wong, K.T.; Li, T.C.M.; Tse, E.C.M.; Chan, J.Y.C.; Yu, J.; Wong, S.S.M.; Choi, K.W.; Wong, R.Y.K.; et al. High Morbidity and Mortality in Adults Hospitalized for Respiratory Syncytial Virus Infections. Clin. Infect. Dis. 2013, 57, 1069-1077. [CrossRef]

24. WHO. Coronavirus Disease (COVID-19) Dashboard. Available online: https://covid19.who.int/ (accessed on 19 May 2020).

25. Russell, C.D.; Fairfield, C.J.; Drake, T.M.; Turtle, L.; Seaton, R.A.; Wootton, D.G.; Sigfrid, L.; Harrison, E.M.; Docherty, A.B.; I de Silva, T.; et al. Co-infections, secondary infections, and antimicrobial use in patients hospitalised with COVID-19 during the first pandemic wave from the ISARIC WHO CCP-UK study: A multicentre, prospective cohort study. Lancet Microbe 2021, 2, e354-e365. [CrossRef]

26. Karami, Z.; Knoop, B.T.; Dofferhoff, A.S.M.; Blaauw, M.J.T.; Janssen, N.A.; van Apeldoorn, M.; Kerckhoffs, A.P.M.; van de Maat, J.S.; Hoogerwerf, J.J.; Oever, J.T. Few bacterial co-infections but frequent empiric antibiotic use in the early phase of hospitalized patients with COVID-19: Results from a multicentre retrospective cohort study in The Netherlands. Infect. Dis. 2021, 53, 102-110. [CrossRef] [PubMed]

27. Hughes, S.; Troise, O.; Donaldson, H.; Mughal, N.; Moore, L. Bacterial and fungal coinfection among hospitalized patients with COVID-19: A retrospective cohort study in a UK secondary-care setting. Clin. Microbiol. Infect. 2020, 26, 1395-1399. [CrossRef]

28. Lansbury, L.; Lim, B.; Baskaran, V.; Lim, W.S. Co-infections in people with COVID-19: A systematic review and meta-analysis. J. Infect. 2020, 81, 266-275. [CrossRef] [PubMed]

29. Langford, B.J.; So, M.; Raybardhan, S.; Leung, V.; Westwood, D.; MacFadden, D.R.; Soucy, J.-P.R.; Daneman, N. Bacterial co-infection and secondary infection in patients with COVID-19: A living rapid review and meta-analysis. Clin. Microbiol. Infect. 2020, 26, 1622-1629. [CrossRef] [PubMed]

30. Garcia-Vidal, C.; Sanjuan, G.; Moreno-García, E.; Puerta-Alcalde, P.; Garcia-Pouton, N.; Chumbita, M.; Fernandez-Pittol, M.; Pitart, C.; Inciarte, A.; Bodro, M.; et al. Incidence of co-infections and superinfections in hospitalized patients with COVID-19: A retrospective cohort study. Clin. Microbiol. Infect. 2021, 27, 83-88. [CrossRef] [PubMed]

31. Chen, N.; Zhou, M.; Dong, X.; Qu, J.; Gong, F.; Han, Y.; Qiu, Y.; Wang, J.; Liu, Y.; Wei, Y.; et al. Epidemiological and clinical characteristics of 99 cases of 2019 novel coronavirus pneumonia in Wuhan, China: A descriptive study. Lancet 2020, 395, 507-513. [CrossRef]

32. Chen, X.; Liao, B.; Cheng, L.; Peng, X.; Xu, X.; Li, Y.; Hu, T.; Li, J.; Zhou, X.; Ren, B. The microbial coinfection in COVID-19. Appl. Microbiol. Biotechnol. 2020, 104, 7777-7785. [CrossRef]

33. Kojima, T.; Go, M.; Takano, K.-I.; Kurose, M.; Ohkuni, T.; Koizumi, J.-I.; Kamekura, R.; Ogasawara, N.; Masaki, T.; Fuchimoto, J.; et al. Regulation of Tight Junctions in Upper Airway Epithelium. BioMed Res. Int. 2013, 2013, 947072. [CrossRef]

34. Pizzorno, A.; Padey, B.; Julien, T.; Trouillet-Assant, S.; Traversier, A.; Errazuriz-Cerda, E.; Fouret, J.; Dubois, J.; Gaymard, A.; Lescure, F.-X.; et al. Characterization and Treatment of SARS-CoV-2 in Nasal and Bronchial Human Airway Epithelia. Cell Rep. Med. 2020, 1, 100059. [CrossRef]

35. De Lamballerie, C.N.; Pizzorno, A.; Dubois, J.; Julien, T.; Padey, B.; Bouveret, M.; Traversier, A.; Legras-Lachuer, C.; Lina, B.; Boivin, G.; et al. Characterization of cellular transcriptomic signatures induced by different respiratory viruses in human reconstituted airway epithelia. Sci. Rep. 2019, 9, 11493. [CrossRef] 
36. Pizzorno, M.A.; Terrier, O.; de Lamballerie, C.N.; Julien, T.; Padey, B.; Traversier, A.; Roche, M.; Hamelin, M.-E.; Rhéaume, C.; Croze, S.; et al. Repurposing of Drugs as Novel Influenza Inhibitors from Clinical Gene Expression Infection Signatures. Front. Immunol. 2019, 10, 60. [CrossRef]

37. Lu, X.; Tumpey, T.M.; Morken, T.; Zaki, S.R.; Cox, N.J.; Katz, J.M. A Mouse Model for the Evaluation of Pathogenesis and Immunity to Influenza A (H5N1) Viruses Isolated from Humans. J. Virol. 1999, 73, 5903-5911. [CrossRef] [PubMed]

38. Imai, M.; Iwatsuki-Horimoto, K.; Hatta, M.; Loeber, S.; Halfmann, P.J.; Nakajima, N.; Watanabe, T.; Ujie, M.; Takahashi, K.; Ito, M.; et al. Syrian hamsters as a small animal model for SARS-CoV-2 infection and countermeasure development. Proc. Natl. Acad. Sci. USA 2020, 117, 16587-16595. [CrossRef] [PubMed]

39. Stittelaar, K.; De Waal, L.; Van Amerongen, G.; Kroeze, E.V.; Fraaij, P.; Van Baalen, C.; Van Kampen, J.; Van Der Vries, E.; Osterhaus, A.; De Swart, R. Ferrets as a Novel Animal Model for Studying Human Respiratory Syncytial Virus Infections in Immunocompetent and Immunocompromised Hosts. Viruses 2016, 8, 168. [CrossRef]

40. Linfield, D.T.; Raduka, A.; Aghapour, M.; Rezaee, F. Airway tight junctions as targets of viral infections. Tissue Barriers 2021, 9 , 1883965. [CrossRef] [PubMed]

41. Rezaee, F.; DeSando, S.A.; Ivanov, A.I.; Chapman, T.J.; Knowlden, S.A.; Beck, L.A.; Georas, S.N. Sustained Protein Kinase D Activation Mediates Respiratory Syncytial Virus-Induced Airway Barrier Disruption. J. Virol. 2013, 87, 11088-11095. [CrossRef]

42. Ruan, T.; Sun, J.; Liu, W.; Prinz, R.A.; Peng, D.; Liu, X.; Xu, X. H1N1 Influenza Virus Cross-Activates Gli1 to Disrupt the Intercellular Junctions of Alveolar Epithelial Cells. Cell Rep. 2020, 31, 107801. [CrossRef]

43. Chertow, D.S.; Kindrachuk, J.; Sheng, Z.-M.; Pujanauski, L.M.; Cooper, K.; Nogee, D.; Claire, M.S.; Solomon, J.; Perry, D.; Sayre, P.; et al. Influenza A and methicillin-resistant Staphylococcus aureus co-infection in rhesus macaques-A model of severe pneumonia. Antivir. Res. 2016, 129, 120-129. [CrossRef]

44. Berendt, R.F.; Long, G.G.; Walker, J.S. Influenza Alone and in Sequence with Pneumonia Due to Streptococcus pneumoniae in the Squirrel Monkey. J. Infect. Dis. 1975, 132, 689-693. [CrossRef]

45. Iverson, A.R.; Boyd, K.L.; McAuley, J.; Plano, L.R.; Hart, M.E.; McCullers, J.A. Influenza Virus Primes Mice for Pneumonia from Staphylococcus aureus. J. Infect. Dis. 2011, 203, 880-888. [CrossRef]

46. Stark, J.M.; Stark, M.A.; Colasurdo, G.N.; Levine, A.M. Decreased bacterial clearance from the lungs of mice following primary respiratory syncytial virus infection. J. Med. Virol. 2006, 78, 829-838. [CrossRef]

47. Morgene, M.F.; Botelho-Nevers, E.; Grattard, F.; Pillet, S.; Berthelot, P.; Pozzetto, B.; Verhoeven, P.O. Staphylococcus aureus colonization and non-influenza respiratory viruses: Interactions and synergism mechanisms. Virulence 2018, 9, 1354-1363. [CrossRef] [PubMed]

48. Braun, L.E.; Sutter, D.E.; Eichelberger, M.C.; Pletneva, L.; Kokai-Kun, J.F.; Blanco, J.C.; Prince, G.A.; Ottolini, M.G. Co-infection of the cotton rat (Sigmodon hispidus) with Staphylococcus aureus and influenza A virus results in synergistic disease. Microb. Pathog. 2007, 43, 208-216. [CrossRef] [PubMed]

49. Schultz-Cherry, S.; Dybdahl-Sissoko, N.; Neumann, G.; Kawaoka, Y.; Hinshaw, V.S. Influenza Virus NS1 Protein Induces Apoptosis in Cultured Cells. J. Virol. 2001, 75, 7875-7881. [CrossRef] [PubMed]

50. Nailwal, H.; Sharma, S.K.; Mayank, A.K.; Lal, S.K. The nucleoprotein of influenza A virus induces p53 signaling and apoptosis via attenuation of host ubiquitin ligase RNF43. Cell Death Dis. 2015, 6, e1768. [CrossRef]

51. Kotelkin, A.; Prikhod'Ko, E.A.; Cohen, J.I.; Collins, P.L.; Bukreyev, A. Respiratory Syncytial Virus Infection Sensitizes Cells to Apoptosis Mediated by Tumor Necrosis Factor-Related Apoptosis-Inducing Ligand. J. Virol. 2003, 77, 9156-9172. [CrossRef]

52. Van Krüchten, A.; Wilden, J.J.; Niemann, S.; Peters, G.; Löffler, B.; Ludwig, S.; Ehrhardt, C. Staphylococcus aureus triggers a shift from influenza virus-induced apoptosis to necrotic cell death. FASEB J. 2018, 32, 2779-2793. [CrossRef]

53. Zanin, M.; Baviskar, P.; Webster, R.; Webby, R. The Interaction between Respiratory Pathogens and Mucus. Cell Host Microbe 2016, 19, 159-168. [CrossRef]

54. Kuek, L.E.; Lee, R.J. First contact: The role of respiratory cilia in host-pathogen interactions in the airways. Am. J. Physiol. Cell. Mol. Physiol. 2020, 319, L603-L619. [CrossRef] [PubMed]

55. McCullers, J.A. Insights into the Interaction between Influenza Virus and Pneumococcus. Clin. Microbiol. Rev. 2006, 19, 571-582. [CrossRef] [PubMed]

56. Hashimoto, K.; Graham, B.S.; Ho, S.B.; Adler, K.B.; Collins, R.D.; Olson, S.J.; Zhou, W.; Suzutani, T.; Jones, P.W.; Goleniewska, K.; et al. Respiratory Syncytial Virus in Allergic Lung Inflammation Increases Muc5ac and Gob-5. Am. J. Respir. Crit. Care Med. 2004, 170, 306-312. [CrossRef]

57. Vareille, M.; Kieninger, E.; Edwards, M.R.; Regamey, N. The Airway Epithelium: Soldier in the Fight against Respiratory Viruses. Clin. Microbiol. Rev. 2011, 24, 210-229. [CrossRef] [PubMed]

58. Hament, J.-M.; Aerts, P.C.; Fleer, A.; van Dijk, H.; Harmsen, T.; Kimpen, J.L.L.; Wolfs, T.F.W. Enhanced Adherence of Streptococcus pneumoniae to Human Epithelial Cells Infected with Respiratory Syncytial Virus. Pediatr. Res. 2004, 55, 972-978. [CrossRef]

59. Hament, J.-M.; Aerts, P.C.; Fleer, A.; van Dijk, H.; Harmsen, T.; Kimpen, J.L.L.; Wolfs, T.F.W. Direct Binding of Respiratory Syncytial Virus to Pneumococci: A Phenomenon that Enhances Both Pneumococcal Adherence to Human Epithelial Cells and Pneumococcal Invasiveness in a Murine Model. Pediatr. Res. 2005, 58, 1198-1203. [CrossRef]

60. Avadhanula, V.; Wang, Y.; Portner, A.; Adderson, E. Nontypeable Haemophilus influenzae and Streptococcus pneumoniae bind respiratory syncytial virus glycoprotein. J. Med. Microbiol. 2007, 56, 1133-1137. [CrossRef] 
61. Mlacha, S.Z.K.; Peret, T.C.T.; Kumar, N.; Romero-Steiner, S.; Hotopp, J.C.D.; Ishmael, N.; Grinblat-Huse, V.; Riley, D.R.; Erdman, D.D.; Carlone, G.M.; et al. Transcriptional adaptation of pneumococci and human pharyngeal cells in the presence of a virus infection. BMC Genom. 2013, 14, 1-14. [CrossRef]

62. Pittet, L.A.; Hall-Stoodley, L.; Rutkowski, M.R.; Harmsen, A.G. Influenza Virus Infection Decreases Tracheal Mucociliary Velocity and Clearance of Streptococcus pneumoniae. Am. J. Respir. Cell Mol. Biol. 2010, 42, 450-460. [CrossRef] [PubMed]

63. Plotkowski, M.-C.; Puchelle, E.; Beck, G.; Jacquot, J.; Hannoun, C. Adherence of Type I Streptococcus pneumoniae to Tracheal Epithelium of Mice Infected with Influenza A/PR8 Virus1-3. Am. Rev. Respir. Dis. 1986, 134, 1040-1044. [CrossRef]

64. McCullers, J.A.; Rehg, J.E. Lethal Synergism between Influenza Virus and Streptococcus pneumoniae: Characterization of a Mouse Model and the Role of Platelet-Activating Factor Receptor. J. Infect. Dis. 2002, 186, 341-350. [CrossRef]

65. Van Der Sluijs, K.F.; Van Elden, L.; Nijhuis, M.; Schuurman, R.; Florquin, S.; Shimizu, T.; Ishii, S.; Jansen, H.M.; Lutter, R.; Van Der Poll, T. Involvement of the platelet-activating factor receptor in host defense against Streptococcus pneumoniae during postinfluenza pneumonia. Am. J. Physiol. Cell. Mol. Physiol. 2006, 290, L194-L199. [CrossRef] [PubMed]

66. Avadhanula, V.; Rodriguez, C.A.; DeVincenzo, J.P.; Wang, Y.; Webby, R.J.; Ulett, G.C.; Adderson, E.E. Respiratory Viruses Augment the Adhesion of Bacterial Pathogens to Respiratory Epithelium in a Viral Species- and Cell Type-Dependent Manner. J. Virol. 2006, 80, 1629-1636. [CrossRef]

67. Sanford, B.A.; Shelokov, A.; Ramsay, M.A. Bacterial Adherence to Virus-Infected Cells: A Cell Culture Model of Bacterial Superinfection. J. Infect. Dis. 1978, 137, 176-181. [CrossRef] [PubMed]

68. Hafez, M.M.; Abdel-Wahab, K.S.E.; El-Fouhil, D.F.I. Augmented adherence and internalization of group A Streptococcus pyogenes to influenza A virus infected MDCK cells. J. Basic Microbiol. 2010, 50 (Suppl. 1), S46-S57. [CrossRef] [PubMed]

69. Davison, V.E.; Sanford, B.A. Factors Influencing Adherence of Staphylococcus aureus to Influenza A Virus-Infected Cell Cultures. Infect. Immun. 1982, 37, 946-955. [CrossRef] [PubMed]

70. Rowe, H.M.; Meliopoulos, V.A.; Iverson, A.; Bomme, P.; Schultz-Cherry, S.; Rosch, J.W. Direct interactions with influenza promote bacterial adherence during respiratory infections. Nat. Microbiol. 2019, 4, 1328-1336. [CrossRef]

71. Peltola, V.T.; Murti, K.G.; McCullers, J.A. Influenza Virus Neuraminidase Contributes to Secondary Bacterial Pneumonia. J. Infect. Dis. 2005, 192, 249-257. [CrossRef] [PubMed]

72. McCullers, J.A.; Bartmess, K.C. Role of Neuraminidase in Lethal Synergism between Influenza Virus and Streptococcus pneumoniae. J. Infect. Dis. 2003, 187, 1000-1009. [CrossRef]

73. Li, N.; Ren, A.; Wang, X.; Fan, X.; Zhao, Y.; Gao, G.F.; Cleary, P.; Wang, B. Influenza viral neuraminidase primes bacterial coinfection through TGF- $\beta$-mediated expression of host cell receptors. Proc. Natl. Acad. Sci. USA 2014, 112, 238-243. [CrossRef]

74. Golda, A.; Malek, N.; Dudek, B.; Zeglen, S.; Wojarski, J.; Ochman, M.; Kucewicz-Czech, E.; Zembala, M.; Potempa, J.; Pyrc, K. Infection with human coronavirus NL63 enhances streptococcal adherence to epithelial cells. J. Gen. Virol. 2011, 92, 1358-1368. [CrossRef] [PubMed]

75. Snelgrove, R.J.; Godlee, A.; Hussell, T. Airway immune homeostasis and implications for influenza-induced inflammation. Trends Immunol. 2011, 32, 328-334. [CrossRef] [PubMed]

76. Martin, P.; Leibovich, S.J. Inflammatory cells during wound repair: The good, the bad and the ugly. Trends Cell Biol. 2005, 15, 599-607. [CrossRef] [PubMed]

77. Pociask, D.A.; Scheller, E.V.; Mandalapu, S.; McHugh, K.J.; Enelow, R.I.; Fattman, C.L.; Kolls, J.K.; Alcorn, J.F. IL-22 Is Essential for Lung Epithelial Repair following Influenza Infection. Am. J. Pathol. 2013, 182, 1286-1296. [CrossRef] [PubMed]

78. Li, W.; Shen, H.-H. Effect of respiratory syncytial virus on the activity of matrix metalloproteinase in mice. Chin. Med. J. 2007, 120, 5-11. [CrossRef] [PubMed]

79. Kash, J.C.; Walters, K.-A.; Davis, A.S.; Sandouk, A.; Schwartzman, L.M.; Jagger, B.W.; Chertow, D.S.; Qi, L.; Kuestner, R.E.; Ozinsky, A.; et al. Lethal Synergism of 2009 Pandemic H1N1 Influenza Virus and Streptococcus pneumoniae Coinfection Is Associated with Loss of Murine Lung Repair Responses. mBio 2011, 2. [CrossRef] [PubMed]

80. Major, J.; Crotta, S.; Llorian, M.; McCabe, T.M.; Gad, H.H.; Priestnall, S.L.; Hartmann, R.; Wack, A. Type I and III interferons disrupt lung epithelial repair during recovery from viral infection. Science 2020, 369, 712-717. [CrossRef]

81. Bellinghausen, C.; Rohde, G.G.U.; Savelkoul, P.H.M.; Wouters, E.F.M.; Stassen, F.R.M. Viral-bacterial interactions in the respiratory tract. J. Gen. Virol. 2016, 97, 3089-3102. [CrossRef]

82. McCullers, J.A. The co-pathogenesis of influenza viruses with bacteria in the lung. Nat. Rev. Genet. 2014, 12, 252-262. [CrossRef]

83. Gordon, S.; Read, R. Macrophage defences against respiratory tract infections. Br. Med. Bull. 2002, 61, 45-61. [CrossRef]

84. Schneider, C.; Nobs, S.P.; Heer, A.K.; Kurrer, M.; Klinke, G.; Van Rooijen, N.; Vogel, J.; Kopf, M. Alveolar Macrophages Are Essential for Protection from Respiratory Failure and Associated Morbidity following Influenza Virus Infection. PLOS Pathog. 2014, 10, e1004053. [CrossRef] [PubMed]

85. Kaplan, M.J.; Radic, M. Neutrophil Extracellular Traps: Double-Edged Swords of Innate Immunity. J. Immunol. 2012, 189, 26892695. [CrossRef] [PubMed]

86. Subramaniam, R.; Barnes, P.F.; Fletcher, K.; Boggaram, V.; Hillberry, Z.; Neuenschwander, P.; Shams, H. Protecting against Post-influenza Bacterial Pneumonia by Increasing Phagocyte Recruitment and ROS Production. J. Infect. Dis. 2014, 209, 1827-1836. [CrossRef]

87. Baral, P.; Batra, S.; Zemans, R.L.; Downey, G.; Jeyaseelan, S. Divergent Functions of Toll-like Receptors during Bacterial Lung Infections. Am. J. Respir. Crit. Care Med. 2014, 190, 722-732. [CrossRef] 
88. Eddens, T.; Kolls, J.K. Host defenses against bacterial lower respiratory tract infection. Curr. Opin. Immunol. 2012, 24, 424-430. [CrossRef] [PubMed]

89. Monroe, K.M.; McWhirter, S.M.; Vance, R.E. Identification of Host Cytosolic Sensors and Bacterial Factors Regulating the Type I Interferon Response to Legionella pneumophila. PLoS Pathog. 2009, 5, e1000665. [CrossRef]

90. Schmolke, M.; Patel, J.R.; de Castro, E.; Sanchez-Aparicio, M.T.; Uccellini, M.; Miller, J.C.; Manicassamy, B.; Satoh, T.; Kawai, T.; Akira, S.; et al. RIG-I Detects mRNA of Intracellular Salmonella enterica Serovar Typhimurium during Bacterial Infection. $m B i o$ 2014, 5, e01006-14. [CrossRef] [PubMed]

91. Zhao, C.; Zhao, W. NLRP3 Inflammasome-A Key Player in Antiviral Responses. Front. Immunol. 2020, 11, 211. [CrossRef]

92. Rodrigues, T.S.; De Sá, K.S.; Ishimoto, A.Y.; Becerra, A.; Oliveira, S.; Almeida, L.; Gonçalves, A.V.; Perucello, D.B.; Andrade, W.A.; Castro, R.; et al. Inflammasomes are activated in response to SARS-CoV-2 infection and are associated with COVID-19 severity in patients. J. Exp. Med. 2021, 218, e20201707. [CrossRef]

93. Tate, M.D.; Mansell, A. An update on the NLRP3 inflammasome and influenza: The road to redemption or perdition? Curr. Opin. Immunol. 2018, 54, 80-85. [CrossRef]

94. Iwasaki, A.; Pillai, P.S. Innate immunity to influenza virus infection. Nat. Rev. Immunol. 2014, 14, 315-328. [CrossRef]

95. Lester, S.N.; Li, K. Toll-Like Receptors in Antiviral Innate Immunity. J. Mol. Biol. 2014, 426, 1246-1264. [CrossRef]

96. Murawski, M.R.; Bowen, G.N.; Cerny, A.M.; Anderson, L.J.; Haynes, L.M.; Tripp, R.; Kurt-Jones, E.A.; Finberg, R.W. Respiratory Syncytial Virus Activates Innate Immunity through Toll-Like Receptor 2. J. Virol. 2009, 83, 1492-1500. [CrossRef]

97. Liu, P.; Jamaluddin, M.; Li, K.; Garofalo, R.P.; Casola, A.; Brasier, A.R. Retinoic Acid-Inducible Gene I Mediates Early Antiviral Response and Toll-Like Receptor 3 Expression in Respiratory Syncytial Virus-Infected Airway Epithelial Cells. J. Virol. 2007, 81, 1401-1411. [CrossRef]

98. Thorne, L.G.; Reuschl, A.; Zuliani-Alvarez, L.; Whelan, M.V.X.; Turner, J.; Noursadeghi, M.; Jolly, C.; Towers, G.J. SARS-CoV-2 sensing by RIG-I and MDA5 links epithelial infection to macrophage inflammation. EMBO J. 2021, 40, e107826. [CrossRef] [PubMed]

99. Zhao, X.; Chu, H.; Wong, B.H.-Y.; Chiu, M.C.; Wang, D.; Li, C.; Liu, X.; Yang, D.; Poon, V.K.-M.; Cai, J.; et al. Activation of C-Type Lectin Receptor and (RIG)-I-Like Receptors Contributes to Proinflammatory Response in Middle East Respiratory Syndrome Coronavirus-Infected Macrophages. J. Infect. Dis. 2020, 221, 647-659. [CrossRef] [PubMed]

100. Segovia, J.; Sabbah, A.; Mgbemena, V.; Tsai, S.-Y.; Chang, T.-H.; Berton, M.T.; Morris, I.R.; Allen, I.; Ting, J.P.-Y.; Bose, S. TLR2/MyD88/NF-kB Pathway, Reactive Oxygen Species, Potassium Efflux Activates NLRP3/ASC Inflammasome during Respiratory Syncytial Virus Infection. PLoS ONE 2012, 7, e29695. [CrossRef]

101. Didierlaurent, A.; Goulding, J.; Patel, S.; Snelgrove, R.; Low, L.; Bebien, M.; Lawrence, T.; Van Rijt, L.S.; Lambrecht, B.N.; Sirard, J.-C.; et al. Sustained desensitization to bacterial Toll-like receptor ligands after resolution of respiratory influenza infection. $J$. Exp. Med. 2008, 205, 323-329. [CrossRef] [PubMed]

102. Martínez-Colón, G.J.; Warheit-Niemi, H.; Gurczynski, S.J.; Taylor, Q.M.; Wilke, C.A.; Podsiad, A.B.; Crespo, J.; Bhan, U.; Moore, B.B. Influenza-induced immune suppression to methicillin-resistant Staphylococcus aureus is mediated by TLR9. PLoS Pathog. 2019, 15, e1007560. [CrossRef]

103. Tian, X.; Xu, F.; Lung, W.Y.; Meyerson, C.; Ghaffari, A.A.; Cheng, G.; Deng, J.C. Poly I:C Enhances Susceptibility to Secondary Pulmonary Infections by Gram-Positive Bacteria. PLoS ONE 2012, 7, e41879. [CrossRef]

104. Robinson, K.M.; Ramanan, K.; Clay, M.; McHugh, K.J.; Pilewski, M.J.; Nickolich, K.L.; Corey, C.; Shiva, S.; Wang, J.; Alcorn, J.F. The inflammasome potentiates influenza/Staphylococcus aureus superinfection in mice. JCI Insight 2018, 3, 97470. [CrossRef]

105. Ghoneim, H.E.; Thomas, P.G.; McCullers, J.A. Depletion of Alveolar Macrophages during Influenza Infection Facilitates Bacterial Superinfections. J. Immunol. 2013, 191, 1250-1259. [CrossRef] [PubMed]

106. Robinson, K.M.; McHugh, K.J.; Mandalapu, S.; Clay, M.E.; Lee, B.; Scheller, E.V.; Enelow, R.I.; Chan, Y.R.; Kolls, J.K.; Alcorn, J.F. Influenza A virus exacerbates Staphylococcus aureus pneumonia in mice by attenuating antimicrobial peptide production. J. Infect. Dis. 2014, 209, 865-875. [CrossRef] [PubMed]

107. Gopal, R.; Lee, B.; McHugh, K.J.; Rich, H.; Ramanan, K.; Mandalapu, S.; Clay, M.; Seger, P.J.; Enelow, R.I.; Manni, M.L.; et al. STAT2 Signaling Regulates Macrophage Phenotype during Influenza and Bacterial Super-Infection. Front. Immunol. $2018,9,2151$. [CrossRef]

108. Sun, K.; Metzger, D. Inhibition of pulmonary antibacterial defense by interferon- $\gamma$ during recovery from influenza infection. Nat. Med. 2008, 14, 558-564. [CrossRef]

109. Raza, M.; Blackwell, C.; Elton, R.; Weir, D. Bactericidal activity of a monocytic cell line (THP-1) against common respiratory tract bacterial pathogens is depressed after infection with respiratory syncytial virus. J. Med. Microbiol. 2000, 49, 227-233. [CrossRef]

110. Arrevillaga, G.; Gaona, J.; Sánchez, C.; Rosales, V.; Gómez, B. Respiratory Syncytial Virus Persistence in Macrophages Downregulates Intercellular Adhesion Molecule-1 Expression and Reduces Adhesion of Non-Typeable Haemophilus influenzae. Intervirology 2012, 55, 442-450. [CrossRef]

111. Sun, K.; Metzger, D. Influenza Infection Suppresses NADPH Oxidase-Dependent Phagocytic Bacterial Clearance and Enhances Susceptibility to Secondary Methicillin-Resistant Staphylococcus aureus Infection. J. Immunol. 2014, 192, 3301-3307. [CrossRef] [PubMed] 
112. Damjanovic, D.; Lai, R.; Jeyanathan, M.; Hogaboam, C.M.; Xing, Z. Marked Improvement of Severe Lung Immunopathology by Influenza-Associated Pneumococcal Superinfection Requires the Control of Both Bacterial Replication and Host Immune Responses. Am. J. Pathol. 2013, 183, 868-880. [CrossRef]

113. Smith, C.M.; Sandrini, S.; Datta, S.; Freestone, P.; Shafeeq, S.; Radhakrishnan, P.; Williams, G.; Glenn, S.M.; Kuipers, O.P.; Hirst, R.A.; et al. Respiratory Syncytial Virus Increases the Virulence of Streptococcus pneumoniae by Binding to Penicillin Binding Protein 1a. A New Paradigm in Respiratory Infection. Am. J. Respir. Crit. Care Med. 2014, 190, 196-207. [CrossRef]

114. Engelich, G.; White, M.; Hartshorn, K. Neutrophil survival is markedly reduced by incubation with influenza virus and Streptococcus pneumoniae: Role of respiratory burst. J. Leukoc. Biol. 2001, 69, 50-56.

115. McNamee, L.A.; Harmsen, A.G. Both Influenza-Induced Neutrophil Dysfunction and Neutrophil-Independent Mechanisms Contribute to Increased Susceptibility to a Secondary Streptococcus pneumoniae Infection. Infect. Immun. 2006, 74, 6707-6721. [CrossRef]

116. Narasaraju, T.; Yang, E.; Samy, R.P.; Ng, H.H.; Poh, W.P.; Liew, A.-A.; Phoon, M.C.; van Rooijen, N.; Chow, V.T. Excessive Neutrophils and Neutrophil Extracellular Traps Contribute to Acute Lung Injury of Influenza Pneumonitis. Am. J. Pathol. 2011, 179, 199-210. [CrossRef]

117. Moorthy, A.N.; Narasaraju, T.; Rai, P.; Perumalsamy, R.; Tan, K.B.; Wang, S.; Engelward, B.; Chow, V.T.K. In Vivo and in Vitro studies on the roles of neutrophil extracellular traps during secondary pneumococcal pneumonia after primary pulmonary influenza infection. Front. Immunol. 2013, 4, 56. [CrossRef]

118. Ellis, G.T.; Davidson, S.; Crotta, S.; Branzk, N.; Papayannopoulos, V.; Wack, A. TRAIL + monocytes and monocyte-related cells cause lung damage and thereby increase susceptibility to influenza- S treptococcus pneumoniae coinfection. EMBO Rep. 2015, 16, 1203-1218. [CrossRef] [PubMed]

119. Small, C.-L.; Shaler, C.R.; McCormick, S.; Jeyanathan, M.; Damjanovic, D.; Brown, E.G.; Arck, P.; Jordana, M.; Kaushic, C.; Ashkar, A.; et al. Influenza Infection Leads to Increased Susceptibility to Subsequent Bacterial Superinfection by Impairing NK Cell Responses in the Lung. J. Immunol. 2010, 184, 2048-2056. [CrossRef] [PubMed]

120. McDermott, D.S.; Weiss, K.A.; Knudson, C.J.; Varga, S.M. Central role of dendritic cells in shaping the adaptive immune response during respiratory syncytial virus infection. Futur. Virol. 2011, 6, 963-973. [CrossRef] [PubMed]

121. Smed-Sörensen, A.; Chalouni, C.; Chatterjee, B.; Cohn, L.; Blattmann, P.; Nakamura, N.; Delamarre, L.; Mellman, I. Influenza A Virus Infection of Human Primary Dendritic Cells Impairs Their Ability to Cross-Present Antigen to CD8 T Cells. PLoS Pathog. 2012, 8, e1002572. [CrossRef]

122. Campana, P.; Parisi, V.; Leosco, D.; Bencivenga, D.; Della Ragione, F.; Borriello, A. Dendritic Cells and SARS-CoV-2 Infection: Still an Unclarified Connection. Cells 2020, 9, 2046. [CrossRef]

123. Schultze, J.L.; Aschenbrenner, A.C. COVID-19 and the human innate immune system. Cell 2021, 184, 1671-1692. [CrossRef]

124. Cavalcante-Silva, L.H.A.; Carvalho, D.C.M.; Lima, D.A.; Galvão, J.G.; Silva, J.S.D.F.D.; de Sales-Neto, J.M.; RodriguesMascarenhas, S. Neutrophils and COVID-19: The road so far. Int. Immunopharmacol. 2021, 90, 107233. [CrossRef]

125. Rynda-Apple, A.; Harmsen, A.; Erickson, A.S.; Larson, K.; Morton, R.V.; Richert, L.E.; Harmsen, A.G. Regulation of IFN- $\gamma$ by IL-13 dictates susceptibility to secondary postinfluenza MRSA pneumonia. Eur. J. Immunol. 2014, 44, 3263-3272. [CrossRef]

126. Van Der Sluijs, K.F.; Van Elden, L.; Nijhuis, M.; Schuurman, R.; Pater, J.M.; Florquin, S.; Goldman, M.; Jansen, H.M.; Lutter, R.; Van Der Poll, T. IL-10 Is an Important Mediator of the Enhanced Susceptibility to Pneumococcal Pneumonia after Influenza Infection. J. Immunol. 2004, 172, 7603-7609. [CrossRef] [PubMed]

127. Van Der Sluijs, K.F.; Nijhuis, M.; Levels, J.H.M.; Florquin, S.; Mellor, A.L.; Jansen, H.M.; Van Der Poll, T.; Lutter, R. InfluenzaInduced Expression of Indoleamine 2,3-Dioxygenase Enhances Interleukin-10 Production and Bacterial Outgrowth during Secondary Pneumococcal Pneumonia. J. Infect. Dis. 2006, 193, 214-222. [CrossRef] [PubMed]

128. Machado, D.; Hoffmann, J.; Moroso, M.; Rosa-Calatrava, M.; Endtz, H.; Terrier, O.; Paranhos-Baccalà, G. RSV Infection in Human Macrophages Promotes CXCL10/IP-10 Expression during Bacterial Co-Infection. Int. J. Mol. Sci. 2017, 18, 2654. [CrossRef]

129. Hoffmann, J.; Machado, D.; Terrier, O.; Pouzol, S.; Messaoudi, M.; Basualdo, W.; Espínola, E.E.; Guillen, R.M.; Rosa-Calatrava, M.; Picot, V.; et al. Viral and bacterial co-infection in severe pneumonia triggers innate immune responses and specifically enhances IP-10: A translational study. Sci. Rep. 2016, 6, 38532. [CrossRef] [PubMed]

130. Kovarik, P.; Castiglia, V.; Ivin, M.; Ebner, F. Type I Interferons in Bacterial Infections: A Balancing Act. Front. Immunol. 2016, 7, 652. [CrossRef] [PubMed]

131. Lee, B.; Robinson, K.M.; McHugh, K.J.; Scheller, E.V.; Mandalapu, S.; Chen, C.; Di, Y.P.; Clay, M.; Enelow, R.I.; Dubin, P.J.; et al. Influenza-induced type I interferon enhances susceptibility to gram-negative and gram-positive bacterial pneumonia in mice. Am. J. Physiol. Cell. Mol. Physiol. 2015, 309, L158-L167. [CrossRef]

132. Kudva, A.; Scheller, E.V.; Robinson, K.M.; Crowe, C.R.; Choi, S.M.; Slight, S.R.; Khader, S.A.; Dubin, P.J.; Enelow, R.I.; Kolls, J.K.; et al. Influenza A Inhibits Th17-Mediated Host Defense against Bacterial Pneumonia in Mice. J. Immunol. 2011, 186, $1666-1674$. [CrossRef] [PubMed]

133. Li, W.; Moltedo, B.; Moran, T.M. Type I Interferon Induction during Influenza Virus Infection Increases Susceptibility to Secondary Streptococcus pneumoniae Infection by Negative Regulation of T Cells. J. Virol. 2012, 86, 12304-12312. [CrossRef]

134. Shahangian, A.; Chow, E.; Tian, X.; Kang, J.R.; Ghaffari, A.; Liu, S.Y.; Belperio, J.A.; Cheng, G.; Deng, J.C. Type I IFNs mediate development of postinfluenza bacterial pneumonia in mice. J. Clin. Investig. 2009, 119, 1910-1920. [CrossRef] [PubMed] 
135. Shepardson, K.M.; Larson, K.; Johns, L.L.; Stanek, K.; Cho, H.; Wellham, J.; Henderson, H.; Rynda-Apple, A. IFNAR2 Is Required for Anti-influenza Immunity and Alters Susceptibility to Post-influenza Bacterial Superinfections. Front. Immunol. 2018, 9, 2589. [CrossRef] [PubMed]

136. Shepardson, K.M.; Larson, K.; Morton, R.V.; Prigge, J.R.; Schmidt, E.E.; Huber, V.C.; Rynda-Apple, A. Differential Type I Interferon Signaling Is a Master Regulator of Susceptibility to Postinfluenza Bacterial Superinfection. mBio 2016, 7, e00506-16. [CrossRef] [PubMed]

137. Planet, P.J.; Parker, D.; Cohen, T.; Smith, H.; Leon, J.D.; Ryan, C.; Hammer, T.J.; Fierer, N.; Chen, E.I.; Prince, A.S. Lambda Interferon Restructures the Nasal Microbiome and Increases Susceptibility to Staphylococcus aureus Superinfection. mBio 2016, 7, e01939-15. [CrossRef]

138. Parker, D. Impact of Type I and III Interferons on Respiratory Superinfections Due to Multidrug-Resistant Pathogens. J. Infect. Dis. 2017, 215, S58-S63. [CrossRef]

139. Abood, R.N.; McHugh, K.J.; Rich, H.E.; Ortiz, M.A.; Tobin, J.M.; Ramanan, K.; Robinson, K.M.; Bomberger, J.M.; Kolls, J.K.; Manni, M.L.; et al. IL-22-binding protein exacerbates influenza, bacterial super-infection. Mucosal Immunol. 2019, 12, 1231-1243. [CrossRef]

140. Robinson, K.M.; Lee, B.; Scheller, E.V.; Mandalapu, S.; Enelow, R.I.; Kolls, J.K.; Alcorn, J.F. The role of IL-27 in susceptibility to post-influenza Staphylococcus aureus pneumonia. Respir. Res. 2015, 16, 10. [CrossRef]

141. Lee, B.; Gopal, R.; Manni, M.L.; McHugh, K.J.; Mandalapu, S.; Robinson, K.M.; Alcorn, J.F. STAT1 Is Required for Suppression of Type 17 Immunity during Influenza and Bacterial Superinfection. ImmunoHorizons 2017, 1, 81-91. [CrossRef] [PubMed]

142. Blevins, L.K.; Wren, J.T.; Holbrook, B.C.; Hayward, S.L.; Swords, W.E.; Parks, G.D.; Alexander-Miller, M.A. Coinfection with Streptococcus pneumoniae Negatively Modulates the Size and Composition of the Ongoing Influenza-Specific CD8+T Cell Response. J. Immunol. 2015, 193, 5076-5087. [CrossRef]

143. Wu, Y.; Tu, W.; Lam, K.-T.; Chow, K.-H.; Ho, P.-L.; Guan, Y.; Peiris, J.S.M.; Lau, Y.-L. Lethal Coinfection of Influenza Virus and Streptococcus pneumoniae Lowers Antibody Response to Influenza Virus in Lung and Reduces Numbers of Germinal Center B Cells, T Follicular Helper Cells, and Plasma Cells in Mediastinal Lymph Node. J. Virol. 2014, 89, 2013-2023. [CrossRef]

144. Wolf, A.I.; Strauman, M.C.; Mozdzanowska, K.; Whittle, J.R.R.; Williams, K.L.; Sharpe, A.H.; Weiser, J.; Caton, A.J.; Hensley, S.E.; Erikson, J. Coinfection with Streptococcus pneumoniae Modulates the B Cell Response to Influenza Virus. J. Virol. 2014, 88, 11995-12005. [CrossRef] [PubMed]

145. Cao, J.; Wang, D.; Xu, F.; Gong, Y.; Wang, H.; Song, Z.; Li, D.; Zhang, H.; Li, D.; Zhang, L.; et al. Activation of IL -27 signalling promotes development of postinfluenza pneumococcal pneumonia. EMBO Mol. Med. 2014, 6, 120-140. [CrossRef] [PubMed]

146. Barthelemy, A.; Ivanov, S.; Fontaine, J.; Soulard, D.; Bouabe, H.; Paget, C.; Faveeuw, C.; Trottein, F. Influenza A virus-induced release of interleukin-10 inhibits the anti-microbial activities of invariant natural killer $\mathrm{T}$ cells during invasive pneumococcal superinfection. Mucosal Immunol. 2017, 10, 460-469. [CrossRef]

147. McAuley, J.; Hornung, F.; Boyd, K.L.; Smith, A.; McKeon, R.; Bennink, J.; Yewdell, J.W.; McCullers, J.A. Expression of the 1918 Influenza A Virus PB1-F2 Enhances the Pathogenesis of Viral and Secondary Bacterial Pneumonia. Cell Host Microbe 2007, 2, 240-249. [CrossRef]

148. McAuley, J.L.; Chipuk, J.E.; Boyd, K.L.; Van De Velde, N.; Green, D.R.; McCullers, J.A. PB1-F2 Proteins from H5N1 and 20th Century Pandemic Influenza Viruses Cause Immunopathology. PLoS Pathog. 2010, 6, e1001014. [CrossRef]

149. Alymova, I.V.; Green, A.M.; Van De Velde, N.; McAuley, J.L.; Boyd, K.L.; Ghoneim, H.E.; McCullers, J.A. Immunopathogenic and Antibacterial Effects of H3N2 Influenza A Virus PB1-F2 Map to Amino Acid Residues 62, 75, 79, and 82. J. Virol. 2011, 85, 12324-12333. [CrossRef]

150. Lyczak, J.B.; Cannon, C.L.; Pier, G.B. Lung Infections Associated with Cystic Fibrosis. Clin. Microbiol. Rev. 2002, 15, 194-222. [CrossRef]

151. Hewitt, R.; Farne, H.; Ritchie, A.; Luke, E.; Johnston, S.; Mallia, P. The role of viral infections in exacerbations of chronic obstructive pulmonary disease and asthma. Ther. Adv. Respir. Dis. 2016, 10, 158-174. [CrossRef] [PubMed]

152. Kotnala, S.; Dhasmana, A.; Kashyap, V.K.; Chauhan, S.C.; Yallapu, M.M.; Jaggi, M. A bird eye view on cystic fibrosis: An underestimated multifaceted chronic disorder. Life Sci. 2021, 268, 118959. [CrossRef] [PubMed]

153. O'Sullivan, B.P.; Freedman, S.D. Cystic fibrosis. Lancet 2009, 373, 1891-1904. [CrossRef]

154. Wat, D.; Gelder, C.; Hibbitts, S.; Cafferty, F.; Bowler, I.; Pierrepoint, M.; Evans, R.; Doull, I. The role of respiratory viruses in cystic fibrosis. J. Cyst. Fibros. 2008, 7, 320-328. [CrossRef]

155. Hendricks, M.R.; Bomberger, J.M. Digging through the Obstruction: Insight into the Epithelial Cell Response to Respiratory Virus Infection in Patients with Cystic Fibrosis. J. Virol. 2016, 90, 4258-4261. [CrossRef] [PubMed]

156. van Ewijk, B.E.; Wolfs, T.F.W.; Aerts, P.C.; Van Kessel, K.P.M.; Fleer, A.; Kimpen, J.L.L.; Van Der Ent, C.K. RSV Mediates Pseudomonas aeruginosa Binding to Cystic Fibrosis and Normal Epithelial Cells. Pediatr. Res. 2007, 61, 398-403. [CrossRef]

157. Kiedrowski, M.R.; Bomberger, J.M. Viral-Bacterial Co-infections in the Cystic Fibrosis Respiratory Tract. Front. Immunol. 2018, 9, 3067. [CrossRef] [PubMed]

158. De Serres, G.; Lampron, N.; La Forge, J.; Rouleau, I.; Bourbeau, J.; Weiss, K.; Barret, B.; Boivin, G. Importance of viral and bacterial infections in chronic obstructive pulmonary disease exacerbations. J. Clin. Virol. 2009, 46, 129-133. [CrossRef] [PubMed] 
159. Molyneaux, P.L.; Mallia, P.; Cox, M.; Footitt, J.; Willis-Owen, S.; Homola, D.; Trujillo-Torralbo, M.-B.; Elkin, S.; Kon, O.M.; Cookson, W.O.C.; et al. Outgrowth of the Bacterial Airway Microbiome after Rhinovirus Exacerbation of Chronic Obstructive Pulmonary Disease. Am. J. Respir. Crit. Care Med. 2013, 188, 1224-1231. [CrossRef]

160. Sigurs, N.; Bjarnason, R.; Sigurbergsson, F.; Kjellman, B. Respiratory Syncytial Virus Bronchiolitis in Infancy Is an Important Risk Factor for Asthma and Allergy at Age 7. Am. J. Respir. Crit. Care Med. 2000, 161, 1501-1507. [CrossRef]

161. Gern, J.E.; Rosenthal, L.A.; Sorkness, R.L.; Lemanske, R.F. Effects of viral respiratory infections on lung development and childhood asthma. J. Allergy Clin. Immunol. 2005, 115, 668-674. [CrossRef]

162. Chang, D.; Cruz, C.S.D.; Sharma, L. Challenges in understanding lung microbiome: It is NOT like the gut microbiome. Respirology 2020, 25, 244-245. [CrossRef]

163. Sommariva, M.; Le Noci, V.; Bianchi, F.; Camelliti, S.; Balsari, A.; Tagliabue, E.; Sfondrini, L. The lung microbiota: Role in maintaining pulmonary immune homeostasis and its implications in cancer development and therapy. Cell. Mol. Life Sci. 2020, 77, 2739-2749. [CrossRef] [PubMed]

164. Piters, W.D.S.; Heinonen, S.; Hasrat, R.; Bunsow, E.; Smith, B.; Suarez-Arrabal, M.-C.; Chaussabel, D.; Cohen, D.M.; Sanders, E.A.M.; Ramilo, O.; et al. Nasopharyngeal Microbiota, Host Transcriptome, and Disease Severity in Children with Respiratory Syncytial Virus Infection. Am. J. Respir. Crit. Care Med. 2016, 194, 1104-1115. [CrossRef]

165. Kaul, D.; Rathnasinghe, R.; Ferres, M.; Tan, G.S.; Barrera, A.; Pickett, B.E.; Methe, B.A.; Das, S.R.; Budnik, I.; Halpin, R.A.; et al. Microbiome disturbance and resilience dynamics of the upper respiratory tract during influenza A virus infection. Nat. Commun. 2020, 11, 2537. [CrossRef] [PubMed]

166. Hanada, S.; Pirzadeh, M.; Carver, K.Y.; Deng, J.C. Respiratory Viral Infection-Induced Microbiome Alterations and Secondary Bacterial Pneumonia. Front. Immunol. 2018, 9, 2640. [CrossRef] [PubMed]

167. Sonawane, A.R.; Tian, L.; Chu, C.-Y.; Qiu, X.; Wang, L.; Holden-Wiltse, J.; Grier, A.; Gill, S.R.; Caserta, M.T.; Falsey, A.R.; et al. Microbiome-Transcriptome Interactions Related to Severity of Respiratory Syncytial Virus Infection. Sci. Rep. 2019, 9, 13824. [CrossRef] [PubMed]

168. Huffnagle, G.B.; Dickson, R.P.; Lukacs, N.W. The respiratory tract microbiome and lung inflammation: A two-way street. Mucosal Immunol. 2017, 10, 299-306. [CrossRef] [PubMed]

169. Richard, A.L.; Siegel, S.J.; Erikson, J.; Weiser, J.N. TLR2 Signaling Decreases Transmission of Streptococcus pneumoniae by Limiting Bacterial Shedding in an Infant Mouse Influenza A Co-infection Model. PLoS Pathog. 2014, 10, e1004339. [CrossRef]

170. Marks, L.; Davidson, B.A.; Knight, P.R.; Hakansson, A.P. Interkingdom Signaling Induces Streptococcus pneumoniae Biofilm Dispersion and Transition from Asymptomatic Colonization to Disease. mBio 2013, 4, e00438-13. [CrossRef]

171. Reddinger, R.M.; Luke-Marshall, N.R.; Hakansson, A.P.; Campagnari, A.A. Host Physiologic Changes Induced by Influenza A Virus Lead to Staphylococcus aureus Biofilm Dispersion and Transition from Asymptomatic Colonization to Invasive Disease. $m$ Bio 2016, 7, e01235-16. [CrossRef]

172. Pettigrew, M.M.; Marks, L.; Kong, Y.; Gent, J.F.; Roche-Hakansson, H.; Hakansson, A.P. Dynamic Changes in the Streptococcus pneumoniae Transcriptome during Transition from Biofilm Formation to Invasive Disease upon Influenza A Virus Infection. Infect. Immun. 2014, 82, 4607-4619. [CrossRef]

173. Kanmani, P.; Clua, P.; Vizoso-Pinto, M.G.; Rodriguez, C.; Alvarez, S.; Melnikov, V.; Takahashi, H.; Kitazawa, H.; Villena, J. Respiratory Commensal Bacteria Corynebacterium pseudodiphtheriticum Improves Resistance of Infant Mice to Respiratory Syncytial Virus and Streptococcus pneumoniae Superinfection. Front. Microbiol. 2017, 8, 1613. [CrossRef] [PubMed]

174. Bruchhagen, C.; Jarick, M.; Mewis, C.; Hertlein, T.; Niemann, S.; Ohlsen, K.; Peters, G.; Planz, O.; Ludwig, S.; Ehrhardt, C. Metabolic conversion of CI-1040 turns a cellular MEK-inhibitor into an antibacterial compound. Sci. Rep. 2018, 8, 9114. [CrossRef] [PubMed]

175. Surmann, K.; Simon, M.; Hildebrandt, P.; Pförtner, H.; Michalik, S.; Stentzel, S.; Steil, L.; Dhople, V.M.; Bernhardt, J.; Schlüter, R.; et al. A proteomic perspective of the interplay of Staphylococcus aureus and human alveolar epithelial cells during infection. J. Proteom. 2015, 128, 203-217. [CrossRef] [PubMed]

176. De Vrankrijker, A.M.; Wolfs, T.F.; Ciofu, O.; Høiby, N.; Van Der Ent, C.K.; Poulsen, S.S.; Johansen, H.K. Respiratory syncytial virus infection facilitates acute colonization of Pseudomonas aeruginosa in mice. J. Med. Virol. 2009, 81, 2096-2103. [CrossRef]

177. Yan, T.; Tang, X.; Sun, L.; Tian, R.; Li, Z.; Liu, G. Co infection of respiratory syncytial viruses (RSV) and Streptococcus pneumonia modulates pathogenesis and dependent of serotype and phase variant. Microb. Pathog. 2020, 144, 104126. [CrossRef]

178. LeVine, A.M.; Koeningsknecht, V.; Stark, J.M. Decreased pulmonary clearance of S. pneumoniae following influenza A infection in mice. J. Virol. Methods 2001, 94, 173-186. [CrossRef]

179. Lee, M.; Arrecubieta, C.; Martin, F.J.; Prince, A.; Borczuk, A.C.; Lowy, F.D. A Postinfluenza Model of Staphylococcus aureus Pneumonia. J. Infect. Dis. 2010, 201, 508-515. [CrossRef]

180. McCullers, J.A.; Webster, R.G. A mouse model of dual infection with influenza virus and Streptococcus pneumoniae. Int. Congr. Ser. 2001, 1219, 601-607. [CrossRef]

181. Kobayashi, S.D.; Olsen, R.J.; LaCasse, R.A.; Safronetz, D.; Ashraf, M.; Porter, A.R.; Braughton, K.R.; Feldmann, F.; Clifton, D.R.; Kash, J.C.; et al. Seasonal H3N2 influenza A virus fails to enhance Staphylococcus aureus co-infection in a non-human primate respiratory tract infection model. Virulence 2013, 4, 707-715. [CrossRef] 
182. Miyake, T.; Soda, K.; Itoh, Y.; Sakoda, Y.; Ishigaki, H.; Nagata, T.; Ishida, H.; Nakayama, M.; Ozaki, H.; Tsuchiya, H.; et al. Amelioration of pneumonia with Streptococcus pneumoniae infection by inoculation with a vaccine against highly pathogenic avian influenza virus in a non-human primate mixed infection model. J. Med. Primatol. 2010, 39, 58-70. [CrossRef]

183. Sanford, B.A.; Ramsay, M.A. In Vivo Localization of Staphylococcus aureus in Nasal Tissues of Healthy and Influenza A VirusInfected Ferrets. Exp. Biol. Med. 1989, 191, 163-169. [CrossRef] [PubMed]

184. Memoli, M.J.; Czajkowski, L.; Reed, S.; Athota, R.; Bristol, T.; Proudfoot, K.; Fargis, S.; Stein, M.; Dunfee, R.L.; Shaw, P.A.; et al. Validation of the Wild-type Influenza A Human Challenge Model H1N1pdMIST: An A(H1N1)pdm09 Dose-Finding Investigational New Drug Study. Clin. Infect. Dis. 2015, 60, 693-702. [CrossRef]

185. Gkatzis, K.; Taghizadeh, S.; Huh, D.; Stainier, D.; Bellusci, S. Use of three-dimensional organoids and lung-on-a-chip methods to study lung development, regeneration and disease. Eur. Respir. J. 2018, 52, 1800876. [CrossRef]

186. Colby, L.E.; Quenee, L.E.; Zitzow, L.A. Considerations for Infectious Disease Research Studies Using Animals. Comp. Med. 2017, 67, 222-231. [PubMed]

187. Han, M.; Rajput, C.; Ishikawa, T.; Jarman, C.R.; Lee, J.; Hershenson, M.B. Small Animal Models of Respiratory Viral Infection Related to Asthma. Viruses 2018, 10, 682. [CrossRef]

188. Bouvier, N.M.; Lowen, A.C. Animal Models for Influenza Virus Pathogenesis and Transmission. Viruses 2010, 2, 1530-1563. [CrossRef] [PubMed]

189. Altamirano-Lagos, M.J.; Díaz, F.E.; Mansilla, M.A.; Rivera-Pérez, D.B.; Soto, D.A.; McGill, J.L.; Vasquez, A.E.; Kalergis, A.M. Current Animal Models for Understanding the Pathology Caused by the Respiratory Syncytial Virus. Front. Microbiol. 2019, 10, 873. [CrossRef]

190. Muñoz-Fontela, C.; Dowling, W.E.; Funnell, S.G.P.; Gsell, P.-S.; Riveros-Balta, A.X.; Albrecht, R.A.; Andersen, H.; Baric, R.S.; Carroll, M.W.; Cavaleri, M.; et al. Animal models for COVID-19. Nature 2020, 586, 509-515. [CrossRef]

191. Reyes, L.F.; Restrepo, M.I.; Hinojosa, C.A.; Soni, N.J.; Shenoy, A.; Gilley, R.P.; Gonzalez-Juarbe, N.; Noda, J.R.; Winter, V.T.; De La Garza, M.A.; et al. A Non-Human Primate Model of Severe Pneumococcal Pneumonia. PLoS ONE 2016, 11, e0166092. [CrossRef]

192. Chen, L.; Welty-Wolf, K.E.; Kraft, B.D. Nonhuman primate species as models of human bacterial sepsis. Lab Anim. 2019, 48, 57-65. [CrossRef]

193. Enkirch, T.; von Messling, V. Ferret models of viral pathogenesis. Virology 2015, 479-480, 259-270. [CrossRef] [PubMed]

194. Peltola, V.T.; Boyd, K.L.; McAuley, J.L.; Rehg, J.E.; McCullers, J.A. Bacterial Sinusitis and Otitis Media following Influenza Virus Infection in Ferrets. Infect. Immun. 2006, 74, 2562-25627. [CrossRef] [PubMed]

195. Diep, B.A.; Hilliard, J.J.; Le, V.T.M.; Tkaczyk, C.; Le, H.N.; Tran, V.G.; Rao, R.L.; Dip, E.C.; Pereira-Franchi, E.P.; Cha, P.; et al. Targeting Alpha Toxin to Mitigate Its Lethal Toxicity in Ferret and Rabbit Models of Staphylococcus aureus Necrotizing Pneumonia. Antimicrob. Agents Chemother. 2017, 61, e02456-16. [CrossRef]

196. Peltola, V.T.; Rehg, J.E.; McCullers, J.E. A ferret model of synergism between influenza virus and Streptococcus pneumoniae. Int. Congr. Ser. 2004, 1263, 486-490. [CrossRef]

197. McCullers, J.A.; McAuley, J.L.; Browall, S.; Iverson, A.R.; Boyd, K.L.; Normark, B.H. Influenza Enhances Susceptibility to Natural Acquisition of and Disease due to Streptococcus pneumoniae in Ferrets. J. Infect. Dis. 2010, 202, 1287-1295. [CrossRef]

198. Nguyen, D.T.; Louwen, R.; Elberse, K.; Van Amerongen, G.; Yüksel, S.; Luijendijk, A.; Osterhaus, A.D.M.E.; Duprex, W.P.; De Swart, R.L. Streptococcus pneumoniae Enhances Human Respiratory Syncytial Virus Infection In Vitro and In Vivo. PLoS ONE 2015, 10, e0127098. [CrossRef]

199. Shirey, K.A.; Perkins, D.J.; Lai, W.; Zhang, W.; Fernando, L.R.; Gusovsky, F.; Blanco, J.C.G.; Vogel, S.N. Influenza “Trains" the Host for Enhanced Susceptibility to Secondary Bacterial Infection. mBio 2019, 10. [CrossRef] [PubMed]

200. Giebink, G.S.; Berzins, I.K.; Marker, S.C.; Schiffman, G. Experimental otitis media after nasal inoculation of Streptococcus pneumoniae and influenza A virus in chinchillas. Infect. Immun. 1980, 445, 450. [CrossRef]

201. Brockson, M.E.; Novotny, L.A.; Jurcisek, J.A.; McGillivary, G.; Bowers, M.R.; Bakaletz, L.O. Respiratory Syncytial Virus Promotes Moraxella catarrhalis-Induced Ascending Experimental Otitis Media. PLoS ONE 2012, 7, e40088. [CrossRef]

202. Jochems, S.P.; Marcon, F.; Carniel, B.F.; Holloway, M.; Mitsi, E.; Smith, E.; Gritzfeld, J.F.; Solórzano, C.; Reiné, J.; Pojar, S.; et al. Inflammation induced by influenza virus impairs human innate immune control of pneumococcus. Nat. Immunol. 2018, 19, 1299-1308. [CrossRef] 